\title{
28. PB-, SR-, AND ND-ISOTOPIC EVOLUTION OF THE LAU BASIN: IMPLICATIONS FOR MANTLE DYNAMICS DURING BACKARC OPENING ${ }^{1}$
}

\author{
J.M. Hergt ${ }^{2,3}$ and C.J. Hawkesworth ${ }^{2}$
}

\begin{abstract}
New $\mathrm{Pb}, \mathrm{Sr}$, and $\mathrm{Nd}$ isotope data are presented for 64 samples from the six backarc sites drilled during Leg 135. Systematic changes in $\mathrm{Pb}$ and $\mathrm{Sr}$ compositions illustrate significant isotopic variations between and within sites as well as provide two key pieces of information. First, a recent influx of asthenosphere with Indian Ocean mantle affinities has occurred and has successfully displaced older "Pacific" asthenosphere from the mantle underlying the backarc region. Second, clear evidence exists for mixing between these two asthenospheric end-members and at least one "arc-like" component. The latter was not the same as most material currently erupting in the Tofua Arc, but it must have had a more radiogenic $\mathrm{Pb}$-isotope signature, perhaps similar to rocks analyzed from the islands of Tafahi, and Niuatoputapu. A comparison between the isotopic variations and the tectonic setting of the drill sites reveals consistent and important information regarding the mantle dynamics beneath the evolving backarc basin. We propose a model in which the source of upwelling magmas changes from Pacific to Indian Ocean asthenosphere with the propagation of seafloor spreading, a model with important implications for the rate of mantle influx into this region. Although the chemistries of backarc magmas have been profoundly influenced by this process, an additional consequence is the advection of Indian Ocean asthenosphere into the sub-arc mantle source. The isotopic compositions of arc rocks from the vicinity have been reevaluated on the basis of the proposed mantle advection model. We suggest that the slab-derived flux of trace elements into the arc wedge has remained relatively uniform with time (i.e., $40 \mathrm{Ma}$ ), so that the change in arc chemistry results from mantle source substitution, rather than from differences in the composition of the downgoing plate.
\end{abstract}

\section{INTRODUCTION}

The Lau backarc basin is a relatively new feature to the southwest Pacific, with opening initiated approximately $6 \mathrm{~m}$.y. ago. Before its rupture and separation, the original arc consisted of the now-dormant Lau Ridge and the eastern side of the Tonga Ridge (Fig. 1). The only exposed igneous basement from the original arc within the Tongan island chain is found on the island of 'Eua. Lying to the west of the older arc constructs of the Tonga Ridge are the modern manifestations of arc magmatism, often referred to as the Tofua Arc (to distinguish between active and ancient arc products). The active Tofua Arc extends southward from the northernmost islands of Tafahi and Niuatoputapu $\left(\sim 15.5^{\circ} \mathrm{S}\right)$ to the island of 'Ata adjacent to the Valu Fa Ridge $\left(\sim 22.5^{\circ} \mathrm{S}\right.$; Fig. 1). The Lau Basin itself lies between the Lau and Tonga ridges, and has been the site of numerous petrological and geochemical studies. Compared with the wealth of major and certain trace element data available, measurements of the $\mathrm{Sr}$ - and $\mathrm{Nd}$-isotopic compositions of the basalts are scarce, and $\mathrm{Pb}$-isotope data are almost nonexistent.

Volpe et al. (1988) studied samples dredged from the central and northeast parts of the Lau Basin and recognized two magma types. Type II is confined to the northeastern area of the basin in the vicinity of Niuafo'ou Island. This area lies outside that covered by drilling during Leg 135, and the magmas would appear to display a significant chemical influence from their proximity to the Samoan ocean island magmatism; as such, material from this region involves additional petrogenetic processes beyond the scope of the current study. Type I is described by Volpe et al. (1988) as including rocks with enriched and depleted trace element abundances; they favored an interpretation whereby normal mid-ocean-ridge basalts (NMORB) interacted with enriched MORB (EMORB)-like peridotite in the basalt source region. Despite the MORB-like Nd-isotopic compositions of basalts from the

\footnotetext{
${ }^{1}$ Hawkins, J., Parson, L., Allan. J., et al., 1994. Proc. ODP, Sci. Results, 135: College Station, TX (Ocean Drilling Program).

${ }^{2}$ Department of Earth Sciences, The Open University, Walton Hall, Milton Keynes. MK7 6AA, United Kingdom.

${ }^{3}$ Present address: School of Earth Sciences, The University of Melbourne, Parkville, Victoria, 3052, Australia.
}

central part of the basin, Volpe et al. (1988) noted that, at a given Nd-isotopic composition, ${ }^{87} \mathrm{Sr} /{ }^{86} \mathrm{Sr}$ is elevated in the Lau Basin rocks relative to MORB. This is consistent with previous observations of comparatively high $\mathrm{Sr}$-isotopic compositions in the Lau Basin basalts made by Gill (1976), Hawkins and Melchior (1985), and Stern (1982).

Other studies have sought to understand the influence of arc proximity on magmas generated at the backarc spreading ridges. Jenner et al. (1987) analyzed samples from the Valu Fa Ridge (and the adjacent island of 'Ata) and noted that the compositions of the backarc basalts have been profoundly influenced by the nearby arc. Subsequent studies have further compared samples from the Valu Fa Ridge with those erupted at sites along the spreading ridges more distant from the arc (e.g., Boespflug et al., 1990; Loock et al., 1990). The consensus of opinion is that, at the Valu Fa Ridge, arc magmatism or a slab-derived flux of trace elements produces melts with strongly arc-like isotopic and trace element signatures. This has been interpreted by Boespflug et al. (1990) either as evidence that the arc volcanic front has migrated into the backarc domain, or that seafloor spreading is in its initial stage at the Valu Fa Ridge.

In contrast, magmas generated during seafloor spreading away from the arc (on the Eastern and Central Lau spreading centers [ELSC and CLSC, respectively]) are similar in composition to enriched MORB, and may show little or no influence from the downgoing plate. Although described as "enriched MORB" by most authors, Loock et al. (1990) used the $\mathrm{Pb}$-isotope compositions of their samples from the central Lau Basin to argue that the underlying mantle was in fact similar to Indian Ocean asthenosphere, and that the convection cell beneath the Indo-Australian Plate extends to this region. Differences between $\mathrm{Pb}$-isotope compositions in their samples from the central Lau Basin and those from the Valu Fa Ridge led Loock et al. (1990) to conclude that the mantle source closer to the arc contained a contribution from Pacific MORB-like material and Pacific sediments.

The proposed backarc drilling sites for Leg 135 were carefully selected so that any basement recovered (i.e., basaltic material from the upper oceanic crust) would span a range in age, from the oldest basaltic products of extension, to material approaching the zero age of the modern spreading axes. Because of the offset between the southward propagating "Central" and retreating "Eastern" Lau 


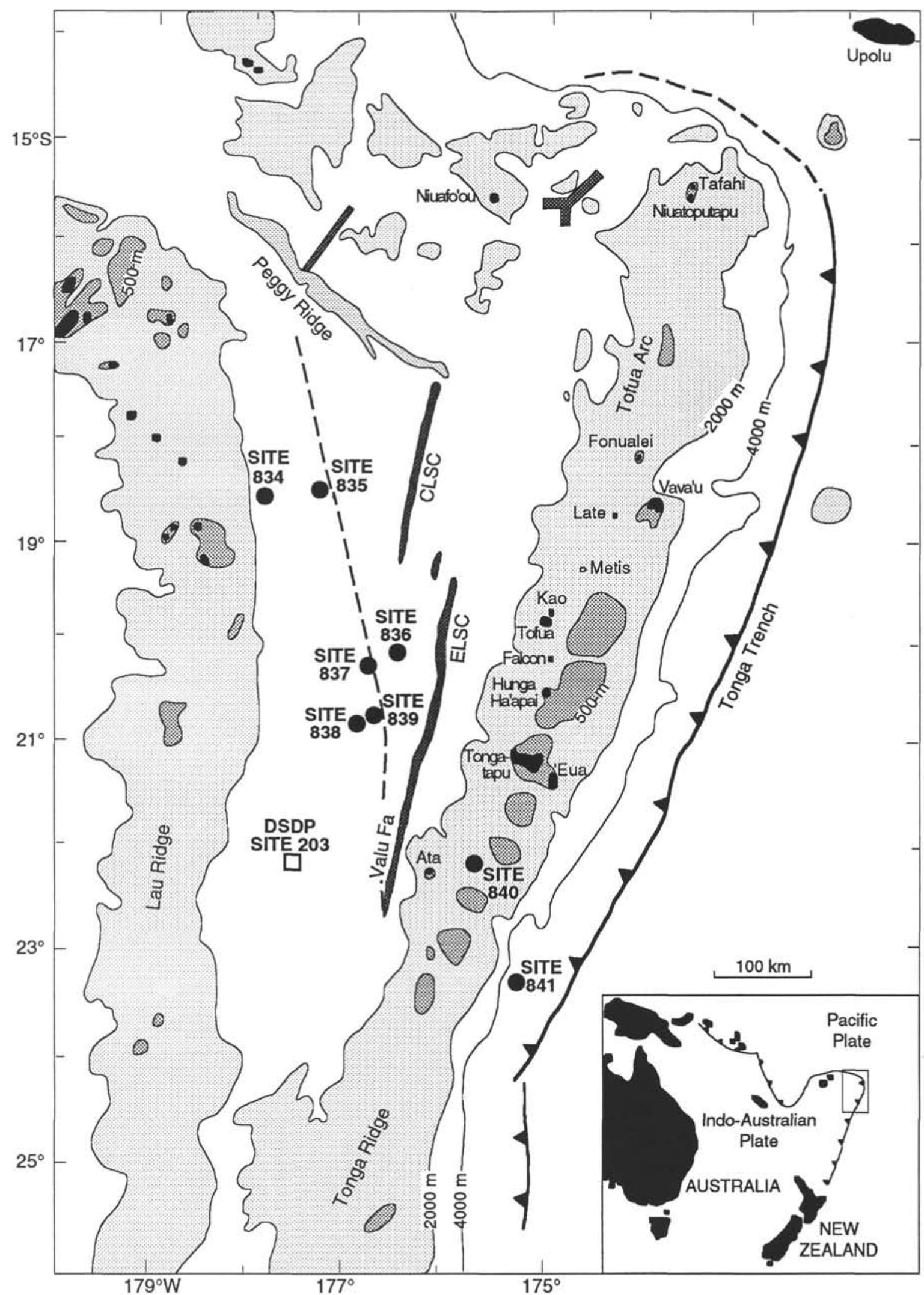

Figure 1. Geography of the Lau Ridge, Lau Basin, and Tonga Ridge, showing the location of sites drilled during Leg 135. CLSC and ELSC refer to the Central and Eastern Lau spreading centers, respectively. The dashed line extending from the Peggy Ridge to the Valu Fa Ridge approximates the locus of the southward-propagating ELSC ridge tip, and also divides the horst-and-graben topography in the west, from new crust formed by true seafloor spreading (to the east). The position of this line is based on the work of Parson and Hawkins (this volume). Light and dark shading is used to represent regions between 2000 and 500 mbsf and between 500 and 0 mbsf, respectively. The darkest gray indicates neovolcanic zones (e.g., ELSC, CLSC). Excluding the drill sites, black depicts land. 
spreading centers, the two sites with oldest basement are located in the northwestern part of the basin; the other four sites are situated farther to the south (Fig. 1). By choosing the sites in this way, it was anticipated that "snapshots" of magmatism (both in style and chemical affinity) would provide some constraints on the evolution of the mantle source, from arc to backarc with time.

The expectation was that the oldest basement intersected, because it formed during the earliest extension within (or adjacent to) the arc, would display chemical affinities closest to those of island-arc basalts. It was reasoned that these signatures would gradually give way to more ocean-ridge-like characteristics with time, approaching those typical of magmas erupting at the present day.

The earliest X-ray fluorescence (XRF) spectrometry results produced on board the JOIDES Resolution demonstrated that our expectations regarding the ages of the basement and their chemical affinities were grossly in error. Some of the units analyzed from the oldest basement (Site 834) were found to be similar in some respects to MORB or materials from the modern spreading centers, whereas samples recovered at Site 839, which is closer to the ELSC, display very strong arc-like characteristics. In this contribution we seek to demonstrate that, despite these apparent complications, a relatively simple magmatic process has been in operation within the Lau Basin.

\section{SAMPLES AND ANALYTICAL TECHNIQUES}

The 64 samples selected from the six backarc sites represent all of the major basaltic units identified by shipboard examination and analysis. Most of the samples are from the glass rinds of pillows or thin sheets; aphyric samples were only selected when glass was unavailable, or when "community" samples were split between the igneous petrologists of the shipboard party (see Bloomer et al., this volume). In one case, a visibly altered portion of the core was sampled together with an adjacent fresh piece to check that the leaching stages were effective in removing surface contamination and/or alteration.

The glass rinds were carefully chiseled from the samples, and the aphyric pieces were cracked, with interior chips picked from the debris. In both cases, the pieces were ultrasoned in acetone (to remove any grease from drilling as well as any traces of the red wax pencil used on board ship to flag sites for sample selection), and carefully rinsed and ultrasoned in ultrapure water. These were then dried, cracked to millimeter-sized chips in a clean agate mortar and pestle, and examined under a binocular microscope, with only the freshest pieces handpicked for analysis.

Approximately 150 -mg-sized samples were weighed into Savillex screw-top beakers. The chips were leached in $1 \mathrm{M} \mathrm{HBr}$ for $30 \mathrm{~min}$ in an ultrasonic bath, and the acid discarded. After rinsing, the samples were further leached in $\sim 3 \mathrm{M} \mathrm{HCl}$ for $30 \mathrm{~min}$ with ultrasoning. To the leached residues were added twice Teflon-distilled HF and nitric acid. The capsules were then capped and placed on a hotplate set at approximately $150^{\circ} \mathrm{C}$ overnight.

The solutions were evaporated to dryness under heating lamps with a flow of clean filtered air. The residues were redissolved in concentrated nitric acid, dried down again, and taken up in $6 \mathrm{M} \mathrm{HCl}$. Typically, the sample capsules were capped and left on a hotplate overnight to ensure that any residues were completely destroyed. The last stage was to dry the samples down again and allow them to leach in $\mathrm{IM} \mathrm{HBr}$ overnight.

Separation of $\mathrm{Pb}$ was achieved using a small-scale ion-exchange technique similar to that of Mahnes et al. (1978), and the eluant was retained for further $\mathrm{Sr}$ and Nd exchange chemistry. The reagents used in both the sample preparation and $\mathrm{Pb}$ extraction chemistry are taken through at least one additional stage of purification compared with those typically used in the $\mathrm{Sr}$ and Nd dissolution procedure in this lab. For this reason, and the fact that very small volumes of $\mathrm{HBr}$ are required in the $\mathrm{Pb}$ extraction, there is no increase in the $\mathrm{Sr}$ or Nd blank for samples prepared in this manner. This single digestion for 3element isotopic extraction was ideal for the limited glass sample size available, and this method is routinely used at the Open University for other types of material in which $\mathrm{Pb}, \mathrm{Sr}$, and $\mathrm{Nd}$ compositions are to be acquired.

The $\mathrm{Pb}$ was loaded onto single $\mathrm{Re}$ filaments with standard ground silica gel and phosphoric acid, and run in static mode on the Finnigan MAT 261 thermal ionization multicollector mass spectrometer at the Open University. The run program used is automatic, and samples were all brought to $1150^{\circ} \mathrm{C}$ for analysis using the built-in optical pyrometer. In addition, with each batch of 10 samples, three NBS 981 standards were also analyzed (being run at the beginning, end, and midway through the unknowns). These efforts at running all samples under the same conditions were designed to control and reproduce the effects of mass fractionation more effectively. The NBS standard results were all normalized to ${ }^{206} \mathrm{~Pb} /{ }^{204} \mathrm{~Pb}=16.937,{ }^{207} \mathrm{~Pb} /{ }^{204} \mathrm{~Pb}=$ 15.491 , and ${ }^{208} \mathrm{~Pb} /{ }^{204} \mathrm{~Pb}=36.702$. Fractionation corrections of $0.9 \%$ per atomic mass unit were applied to the unknowns based on the standard data, and $2 \sigma$ external uncertainties are approximately $0.5 \%$ (for ${ }^{206} \mathrm{~Pb} /{ }^{204} \mathrm{~Pb}$ and ${ }^{207} \mathrm{~Pb} /{ }^{204} \mathrm{~Pb}$ ) and $0.8 \%$ (for ${ }^{208} \mathrm{~Pb} /{ }^{204} \mathrm{~Pb}$ ).

The eluant retained from the $\mathrm{Pb}$ chemistry was dried down with nitric acid and redissolved in $6 \mathrm{M} \mathrm{HCl}$. This was dried down again, and the residue taken up in $2 \mathrm{~mL}$ of $2.5 \mathrm{M} \mathrm{HCl}$. Separation of $\mathrm{Sr}$ and $\mathrm{Nd}$ was achieved using standard cation exchange techniques. The $\mathrm{Sr}$ and Nd concentrates were run on the Finnigan MAT 261 multicollector mass spectrometer in static mode. Strontium was loaded onto single Ta filaments with phosphoric acid, whereas $\mathrm{Nd}$ was loaded onto the Ta side of a Ta-Re double filament assembly with water. Uncertainties $(2 \sigma)$ on separate loads of standards are estimated at 0.710220 \pm 0.000030 (in the case of NBS 987) and $0.511840 \pm 0.000019$ (for the in-house $\mathrm{Nd}$ standard).

Trace element analyses for these same samples were also performed, with data acquired using the technique of inductively coupled plasma mass spectrometry (ICPMS). Although a detailed study of the trace element concentrations is not within the scope of this contribution, we will make some brief comparisons among the sites. For this reason, an account of the sample preparation is not given here, and the reader is directed to Hergt and Sims (this volume).

\section{RESULTS}

Results of the isotopic analyses are given in Table 1, listed in order of site and core locality (from top to bottom). The petrological unit designations applied during Leg 135 are also given. Included in this table are the results from comparisons between leached and nonleached samples. It should be noted that the six "community" samples were not leached, as these are very finely ground powders. No significant differences exist between comparable samples, which might indicate that leaching was not entirely necessary for most samples. Although some variation is evident in the data from Unit 4 (including Subunits 4a and 4b) from Site 836, this does not correlate with the sample preparation involved. Sample $135-836 \mathrm{~A}-9 \mathrm{X}-2,16-24 \mathrm{~cm}$, is visibly very altered and displays yellowed replacement of feldspar and a white clay material lining the vesicle walls. This rock was subjected to the same leaching stages as the other samples, and the data are very close to the results obtained for the other members of the same unit. As a result of these tests, we are confident that the leaching procedures were adequate and that the data presented in Table 1 could not be improved by more elaborate sample preparation techniques.

\section{$\mathrm{Sr}$ and $\mathrm{Nd}$ Isotopes}

The $\mathrm{Sr}$-isotopic compositions vary significantly beyond analytical uncertainties (0.70252-0.70361). Some samples from Site 834 (Unit 7) lie within the range for Pacific Ocean ridge basalts and represent the least radiogenic $\mathrm{Sr}$ compositions reported for basalts from the Lau Basin thus far (see also Hergt and Nilsson, this volume). The ${ }^{87} \mathrm{Sr} /{ }^{86} \mathrm{Sr}$ ratios for the other sites are more radiogenic and are similar to compositions measured in modern Lau Basin magmas (ML). 
Table 1. $\mathrm{Pb}, \mathrm{Sr}$, and $\mathrm{Nd}$ isotope data for samples from the six backarc sites drilled during Leg 135.

\begin{tabular}{|c|c|c|c|c|c|c|}
\hline $\begin{array}{l}\text { Core, section, } \\
\text { interval }(\mathrm{cm})\end{array}$ & $\begin{array}{l}\text { Unit or } \\
\text { subunit }\end{array}$ & ${ }^{206} \mathrm{~Pb} /{ }^{204} \mathrm{~Pb}$ & ${ }^{207} \mathrm{~Pb} /{ }^{204} \mathrm{~Pb}$ & ${ }^{2008} \mathrm{~Pb} /{ }^{204} \mathrm{~Pb}$ & ${ }^{87} \mathrm{Sr} r^{86} \mathrm{Sr}$ & ${ }^{143} \mathrm{Nd} /{ }^{144} \mathrm{Nd}$ \\
\hline \multicolumn{7}{|l|}{$135-834 \mathrm{~B}-$} \\
\hline $8 \mathrm{R}-2,10-13$ & 2 & 18.781 & 15.554 & 38.428 & 0.702841 & 0.513111 \\
\hline $11 \mathrm{R}-3,83-86$ & 5 & 18.738 & 15.529 & 38.324 & 0.702782 & 0.513121 \\
\hline $13 \mathrm{R}-1,130-131^{\circ}$ & 5 & 18.730 & 15.528 & 38.333 & & \\
\hline $14 \mathrm{R}-1,28-32$ & 6 & 18.643 & 15.509 & 38.177 & 0.702626 & \\
\hline $15 \mathrm{R}-2,35-37$ & 6 & 18.617 & 15.480 & 38.093 & 0.702674 & 0.513122 \\
\hline $15 R-2,96-104$ & 6 & 18.638 & 15.500 & 38.147 & 0.702618 & 0.513125 \\
\hline $18 \mathrm{R}-1,7-13$ & 6 & 18.584 & 15.505 & 38.095 & 0.702637 & 0.513123 \\
\hline $26 \mathrm{R}-1,107-109$ & 7 & 18.561 & 15.482 & 38.027 & 0.702524 & \\
\hline 31R-1, 98-104 & 7 & 18.572 & 15.476 & 38.026 & 0.702542 & 0.513109 \\
\hline $31 \mathrm{R}-2,43-48$ & 7 & 18.593 & 15.502 & 38.035 & & 0.513122 \\
\hline $33 R-1,0-6$ & 7 & 18.572 & 15,467 & 38.028 & & 0.513113 \\
\hline $33 R-2,105-110^{*}$ & 7 & 18.605 & 15.494 & 38.081 & 0.702544 & \\
\hline $34 \mathrm{R}-2,60-63$ & 8 & 18.767 & 15.527 & 38.384 & 0.702774 & \\
\hline $35 \mathrm{R}-1,15-23$ & 8 & 18.769 & 15.534 & 38.398 & 0.702746 & \\
\hline $35 \mathrm{R}-2,77-83$ & 8 & 18.790 & 15.546 & 38.425 & 0.702776 & 0.513119 \\
\hline $36 \mathrm{R}-1,0-7$ & 8 & 18.776 & 15.534 & 38.395 & 0.702958 & \\
\hline $37 \mathrm{R}-2,42-44$ & $10 \mathrm{a}$ & 18.677 & 15.534 & 38.395 & 0.702780 & 0.513117 \\
\hline $39 \mathrm{R}-1,9-15$ & $10 \mathrm{a}$ & 18.722 & 15.523 & 38.297 & & 0.513121 \\
\hline $40 \mathrm{R}-1,45-47$ & $10 \mathrm{a}$ & 18.732 & 15.533 & 38.328 & 0.702914 & 0.513111 \\
\hline $46 \mathrm{R}-1,37-40$ & 11 & 18.680 & 15.514 & 38.245 & 0.702808 & 0.513109 \\
\hline $47 \mathrm{R}-1,130-135$ & 12 & 18.731 & 15.516 & 38.293 & 0.702868 & \\
\hline $49 \mathrm{R}-1,142-144$ & 12 & 18.712 & 15.495 & 38.243 & 0.702896 & 0.513113 \\
\hline $53 \mathrm{R}-1,7-20$ & 12 & 18.738 & 15.525 & 38.320 & 0.702891 & 0.513110 \\
\hline $56 \mathrm{R}-2,111-118$ & 13 & 18.701 & 15.518 & 38.275 & 0.702802 & 0.513116 \\
\hline $59 \mathrm{R}-2,52-55$ & 13 & 18.700 & 15.512 & 38.270 & 0.702811 & \\
\hline \multicolumn{7}{|l|}{$135-835 \mathrm{~B}-$} \\
\hline $3 \mathrm{R}-1,123-127$ & 1 & 18.704 & 15.547 & 38.340 & 0.702935 & 0.513079 \\
\hline $3 R-2,0-4$ & 1 & 18.688 & 15.540 & 38.302 & 0.702963 & 0.513086 \\
\hline $4 \mathrm{R}-1,73-78$ & 1 & 18.705 & 15.560 & 38.351 & 0.702927 & 0.513066 \\
\hline $5 \mathrm{R}-1,14-21$ & i & 18.686 & 15.546 & 38.321 & & \\
\hline $7 \mathrm{R}-2,75-84^{*}$ & 1 & 18.655 & 15.503 & 38.194 & 0.703078 & \\
\hline $7 \mathrm{R}-3,135-140$ & 1 & 18.680 & 15.530 & 38.282 & 0.702940 & 0.513079 \\
\hline \multicolumn{7}{|l|}{$135-836 \mathrm{~A}-$} \\
\hline $3 \mathrm{H}-3,23-24$ & 1 & 18.485 & 15.548 & 38.154 & 0.703189 & 0.513073 \\
\hline $3 \mathrm{H}-3,30-95$ & 1 & 18.458 & 15.523 & 38.075 & 0.703237 & \\
\hline $3 \mathrm{H}-3,33-43^{\circ}$ & $i$ & 18.502 & 15.542 & 38.139 & 0.703273 & \\
\hline $3 \mathrm{H}-4,53-110$ & 2 & 18.485 & 15.523 & 38.086 & 0.703250 & 0.513057 \\
\hline $3 \mathrm{H}-4,88-100^{\circ}$ & 2 & 18.511 & 15.536 & 38.140 & 0.703424 & \\
\hline $3 \mathrm{H}-\mathrm{CC}, 0-7$ & 3 & 18.357 & 15.523 & 38.041 & 0.702967 & 0.513025 \\
\hline $9 \mathrm{X}-1.54-58$ & 4 & 18.330 & 15.497 & 37.974 & 0.703016 & 0.513042 \\
\hline $9 \mathrm{X}-2,16-24^{* *}$ & 4 & 18.346 & 15.513 & 38.000 & 0.703109 & \\
\hline \multicolumn{7}{|l|}{$135-836 \mathrm{~B}-$} \\
\hline $3 R-1,47-52$ & $4 a$ & 18.401 & 15.528 & 38.089 & 0.703578 & 0.513052 \\
\hline $5 R-2,65-74$ & $4 \mathrm{~b}$ & 18.356 & 15.510 & 38.004 & 0.703557 & \\
\hline $6 \mathrm{R}-2,20-25$ & $4 b$ & 18.335 & 15.505 & 38.001 & 0.702998 & \\
\hline $7 R-2,62-67$ & 5 & 18.279 & 15.536 & 37.958 & 0.703236 & 0.513065 \\
\hline $9 \mathrm{M}-1,97-102$ & & 18.530 & 15.533 & 38.170 & 0.703174 & 0.513061 \\
\hline \multicolumn{7}{|l|}{$135-837 \mathrm{~B}-$} \\
\hline $2 \mathrm{R}-1,59-63$ & 1 & 18.519 & 15.516 & 38.142 & 0.703194 & 0.513049 \\
\hline $4 \mathrm{R}-1,101-109$ & 1 & 18.543 & 15.5 & 38.2 & 0.703225 & 0.513058 \\
\hline $5 R-1,86-92$ & 1 & 18.547 & 15.535 & 38.189 & 0.703225 & 0.513014 \\
\hline \multicolumn{7}{|l|}{$135-838 \mathrm{~A}-$} \\
\hline $20 \mathrm{H}-1,50-110$ & 1 & 18.910 & 15.559 & 38.548 & 0.703611 & 0.513116 \\
\hline \multicolumn{7}{|l|}{ 135-839B- } \\
\hline $12 \mathrm{R}-2,84-87$ & 1 & 18.684 & 15.539 & 38.261 & & \\
\hline 13R-3, $100-104$ & i & 18.710 & 15.548 & 38.293 & 0.703201 & \\
\hline $18 \mathrm{R}-1,0-6$ & 2 & 18.674 & 15.519 & 38.192 & & 0.513062 \\
\hline $19 \mathrm{R}-1,0-5$ & 2 & 18.689 & 15.536 & 38.247 & 0.703081 & 0.513059 \\
\hline $19 \mathrm{R}-1,15-19$ & 3 & 18.659 & 15.518 & 38.182 & & 0.513074 \\
\hline $19 \mathrm{R}-1,38-41$ & 3 & 18.654 & 15.514 & 38.168 & 0.703040 & 0.513074 \\
\hline $21 \mathrm{R}-1,53-56$ & 3 & 18.659 & 15.519 & 38.170 & & 0.513089 \\
\hline $23 \mathrm{R}-1,32-35$ & 3 & 18.676 & 15.535 & 38.222 & & 0.513084 \\
\hline $25 \mathrm{R}-1,48-53$ & 4 & 18.664 & 15.536 & 38.198 & 0.703093 & 0.513092 \\
\hline $27 \mathrm{R}-1,7-11$ & 5 & 18.712 & 15.545 & 38.280 & 0.703175 & 0.513082 \\
\hline $27 \mathrm{R}-1,29-33$ & 6 & 18.667 & 15.523 & 38.193 & 0.703043 & 0.513079 \\
\hline $29 \mathrm{R}-1,39-43$ & 9 & 18.712 & 15.540 & 38.264 & 0.703173 & 0.513084 \\
\hline $29 \mathrm{R}-1,121-126$ & 9 & 18.692 & 15.522 & 38.209 & 0.703159 & 0.513056 \\
\hline $36 \mathrm{R}-1,32-37$ & 9 & 18.663 & 15.537 & 38.219 & 0.703407 & 0.513094 \\
\hline $37 \mathrm{R}-1,1-5$ & 9 & 18.659 & 15.530 & 38.193 & 0.703116 & 0.513096 \\
\hline $42 \mathrm{R}-1,0-6$ & 9 & 18.669 & 15.515 & 38.176 & & 0.513086 \\
\hline
\end{tabular}

Note: Standard values associated with the literature data used in figures 2 and 3 lie within our own uncertainty and no corrections have been applied before plotting these diagrams. Samples with an asterisk $\left(^{*}\right)$ represent unleached "community" samples; the sample with a double asterisk $\left({ }^{* *}\right)$ was visibly very altered.

In contrast with the $\mathrm{Sr}$-isotopic compositions, ${ }^{143} \mathrm{Nd} /{ }^{144} \mathrm{Nd}$ ratios are remarkably uniform in the rocks from all sites $(0.51301-0.51313)$. The samples from Sites 834 and 838 tend to have slightly higher values compared with the other data (with averages closer to 0.51312); nevertheless, the ${ }^{143} \mathrm{Nd} /{ }^{144} \mathrm{Nd}$ ratios show only very small variations beyond the estimated uncertainties.
The Sr- and Nd-isotopic results are illustrated in Figure 2, accompanied by other relevant fields of interest. The "original arc" is represented by data from the Lau Volcanic Group and 'Eua (also Site 841; see Bloomer et al., this volume). Although the Tofua Arc strictly includes all of the active islands, certain geochemical differences exist that make some distinctions necessary. For example, although most of the islands have $\mathrm{Sr}$-isotope compositions between $\sim 0.7035$ and 0.7037 , the single analysis for 'Ata has a value of $\sim 0.7033$ (which is more similar to the compositions observed in the original arc), and the northernmost islands plot between $\sim 0.7039$ and 0.704 . For this reason, we refer to the Tofua Arc as all active islands excluding 'Ata, Tafahi, and Niuatoputapu. The fact that the variations appear to be within both the northernmost and southernmost products of magmatism is important, and will be discussed in more detail in following sections. Finally, fields for samples from the ML (including the Valu Fa Ridge [VF]) are given, as are fields for Pacific and Indian ocean MORB. The similarity between the single value for 'Ata and published data for samples from the Valu Fa Ridge (adjacent to 'Ata) supports the unusual composition of this young arc magma relative to the rest of the Tofua Arc and also emphasizes the similarity between the isotopic compositions of the modern arc and backarc at this locality.

Many of the new data are clearly displaced from the field for the Tofua Arc and the modern Lau Basin toward lower Sr values, but they share similar Nd-isotopic compositions with basalts at the higher ${ }^{143} \mathrm{Nd} /{ }^{144} \mathrm{Nd}$ end of the modern Lau Basin field. Products from the original arc tend toward less radiogenic $\mathrm{Sr}$ compositions and higher Nd-isotope values compared with most samples from the Tofua Arc (and many ML rocks, in the case of the Lau Volcanic Group).

\section{$\mathrm{Pb}$ Isotopes}

Figure 3 illustrates the $\mathrm{Pb}$-isotopic compositions of the samples from each site relative to a number of other fields for comparison. On a broad scale, a number of key features are worth noting. First, the new data clearly define two distinct trends that converge at high values of ${ }^{206} \mathrm{~Pb} /{ }^{204} \mathrm{~Pb}$. One of these projects backs into the field for Pacific MORB and includes samples from Sites 834 and 839, whereas the other trend includes samples from Sites 836 and 837 and projects into the field defined by MORB from the Indian Ocean (and data from rocks dredged from the ML). Data for samples from Site 835 plot close to the intersection between these trends.

The second observation is that the samples from the "Pacific" trend are generally higher in ${ }^{206} \mathrm{~Pb} /{ }^{204} \mathrm{~Pb}$ compared with most rocks from the modern Tofua Arc, the exception being that they are lower when compared with limited data from the islands of Tafahi and Niuatoputapu (Ewart and Hawkesworth, 1987). In contrast, samples from Sites 836 and 837 plot within (or at lower) ${ }^{206} \mathrm{~Pb} /{ }^{204} \mathrm{~Pb}$ compared with the Tofua samples. A hyaloclastite unit from Site 838 is the most radiogenic material yet analyzed from the Lau Basin, plotting within (or close to) the field for rocks from Tafahi.

In detail, ranges in $\mathrm{Pb}$-isotope compositions from individual sites provide clear evidence for mixing. Figure 4 shows the results for Site 834 plotted vs. depth (in meters below seafloor [mbsf]). The individual unit designations are identified and indicate something of a "cyclic" variation in the $\mathrm{Pb}$-isotopic compositions. The gradual increase in ratios uphole from Unit 13 to Unit 8 ends abruptly with the sharp drop in values in Unit 7. Above this, the ratios increase again until, in Unit 2 , they are similar to the peak observed in Unit 8 . Although noted here, this scale of variation is more closely examined in Hergt and Nilsson (this volume). These authors noted correlations between $\mathrm{Pb}$-isotope ratios and key trace element ratios such as $\mathrm{Ba} / \mathrm{Nb}$, and concluded that these resulted from various mixtures between arc and MORB magmas. The cyclic variation was considered to be consistent with the extensional regime, closely approximating that of slow mid-ocean-ridge spreading centers. Large variations in chemistry are expected in this tectonic setting because of the incomplete homogenization that occurred before eruption (Sinton and Detrick, 1992), and, given the avail- 


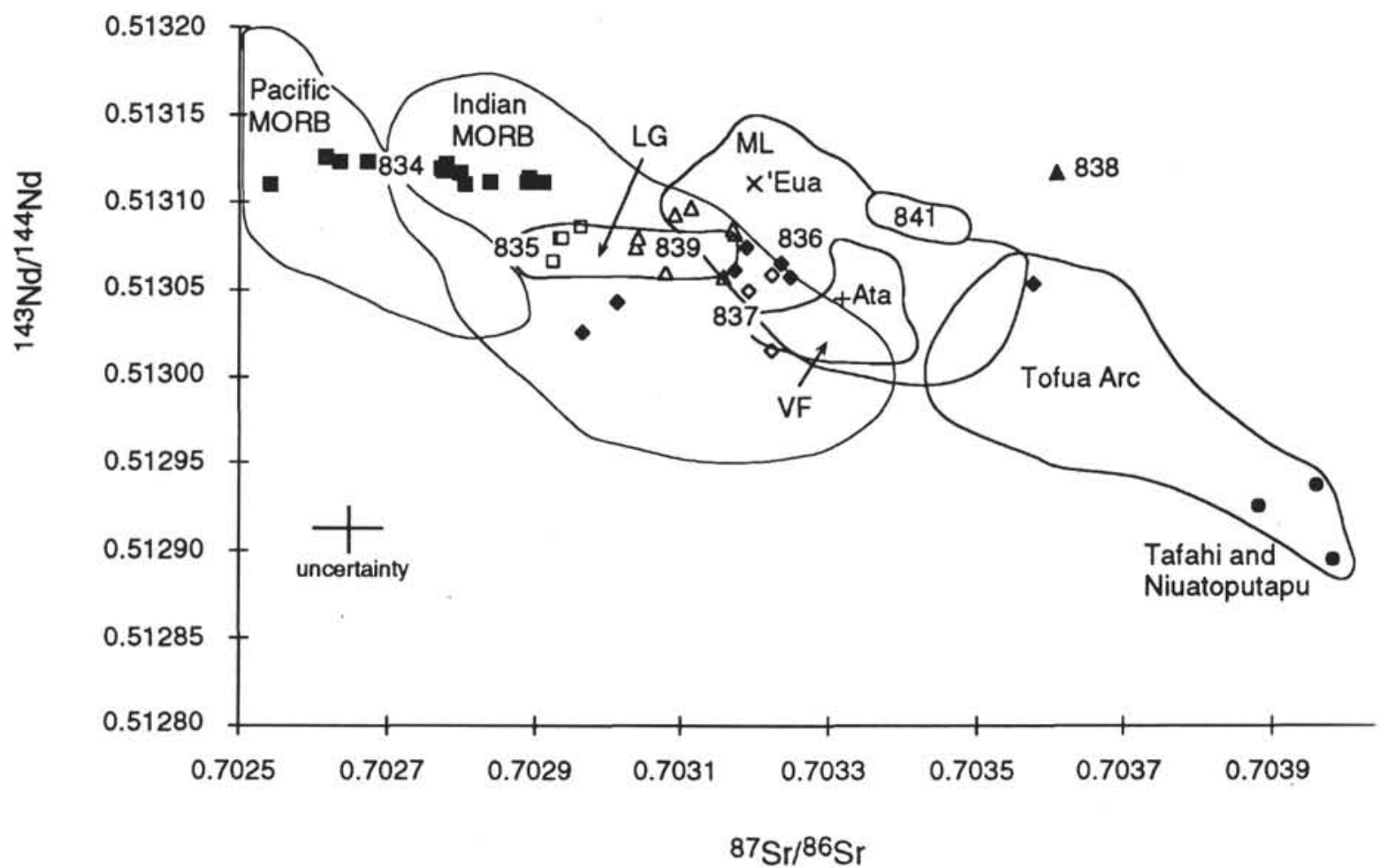

Figure 2. Nd vs. Sr isotope variation diagram illustrating the compositions of the new data for Lau Basin samples relative to MORB and other rocks from the region. MORB data are compiled from Mahoney et al. (1993) and references therein. The data for the Lau Volcanic Group (LG) are from Cole et al. (1990). Tofua Arc data are from Ewart and Hawkesworth (1987) and references therein. The field for the modern Lau spreading centers (ML) is based on Volpe et al. (1988), Boespflug et al. (1990), Loock et al. (1990), and J.M. Hergt (unpubl. data). The Valu Fa results (VF) are from Jenner et al. (1987).

ability of arc and MORB end-members, this variation is significantly enhanced at Site 834.

\section{DISCUSSION}

It is clear from the $\mathrm{Pb}$-isotope data alone that magmatism in the backarc basin was the product of mixing between an asthenospheric "MORB" end-member and an arc-like component (perhaps broadly similar to that represented by Tafahi and Niuatoputapu). These data also demonstrate that there have been two sources for the MORB endmember: one similar to Pacific asthenosphere, and the other with a Pbisotope composition more like Indian Ocean asthenosphere (i.e., Fig. 3).

In this volume, Parson and Hawkins describe new geophysical data and propose a model for the tectonic history involved in the opening of the Lau Basin. Using this information to reexamine the $\mathrm{Pb}$-isotope variations, a clear pattern emerges. To demonstrate this, it is necessary briefly to outline some of the major points of the model, and the following description of the tectonic evolution of the Lau Basin is entirely summarized from their work.

\section{Tectonic History}

At some time between $\sim 7$ and $6 \mathrm{Ma}$, extension within the arc formed horst-and-graben features that heralded the initial stages of backarc opening. At approximately $5.5 \mathrm{Ma}$, magmatism occurred in one such graben at Site 834, whereas farther to the northeast a propagating ridge was being initiated. The tip of the propagator migrated southward from the Peggy Ridge along the western side of what was to become the Tonga Ridge. Axial spreading resulted in a fan-shaped opening in the northeastern part of the basin, whereas horst-and-graben style extension continued in the southwest. At the time magmatism took place at Site 835 , the propagating tip was in the vicinity (possibly having just moved passed this point, at most, 0.5 m.y. earlier). Later, at approximately $2 \mathrm{Ma}$, magmatism occurred at Site 837 , roughly coincident with the arrival of the propagator. At the same time, but farther south, basalts were erupting in the block extensional regime at Site 839 preceding the arrival of the propagating ridge. Later ( 1 Ma), at Site 836 , basalts were erupted at the newly formed spreading center in a manner similar to that currently occurring at the ELSC. The single sample analyzed from Site 838 represents a hyaloclastite unit rather than basement. This unit is thought to be greater than $\sim 1.8 \mathrm{~m}$.y. old, on the basis of paleontological assemblages observed in the sediments (Parson, Hawkins, Allan, et al., 1992), and would place the magmatism in a similar geographic and temporal setting to the rocks from Site 839 .

Comparison between the $\mathrm{Pb}$-isotope variations and the tectonic history outlined above reveals that basement from Sites 834 and 839 occurs entirely within the extended older arc crust that forms the horstand-graben fabric of the western Lau Basin, whereas Sites 836 and 837 are located within the new crust generated by true seafloor spreading (Fig. 1). The nature of the basement from Site 835 is somewhat contentious, because of problems in precisely defining an age for the overlying sediments. At present, it would appear that some horst-andgraben-style extension continued to generate melting in this area, even after the propagator had initiated seafloor spreading in the vicinity.

In summary, basalts with Pacific MORB affinities are located within the older extended crust, whereas those with Indian MORB Pb signatures are generated within crust formed at the new spreading center. This correlation between the migration of the propagator and a change in the asthenospheric end-member has had a number of important consequences for the evolution of the mantle beneath the Lau Basin as well as for the compositional evolution of the arc itself. 

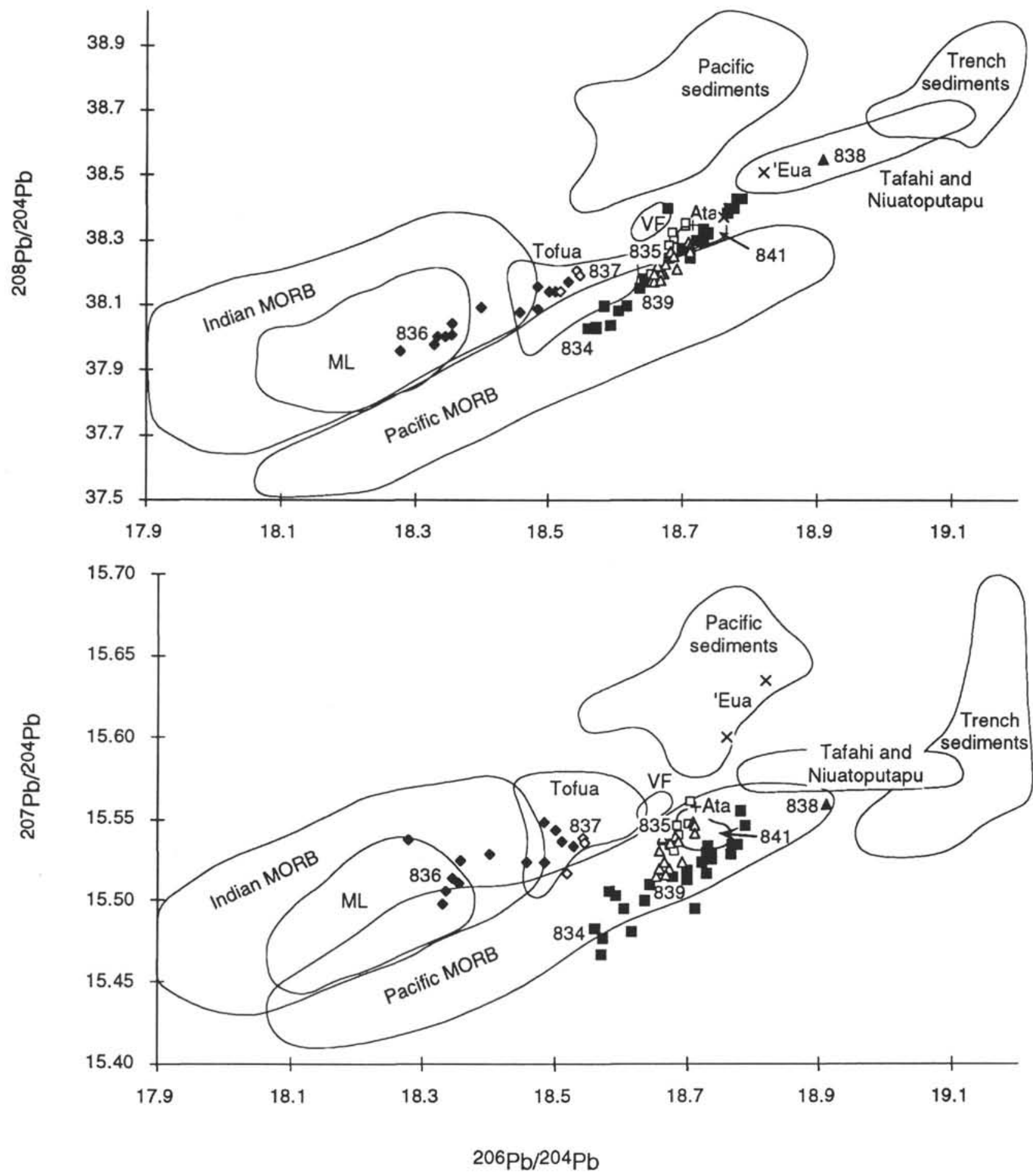

Figure 3. Variation diagram illustrating the $\mathrm{Pb}$-isotope compositions of Leg 135 samples relative to MORB and other rocks from the local area. Data sources are included in those given in the caption to Figure 2; in addition, the Pb compositions for Pacific and trench sediments are from Sun (1980), Ben Othman et al. (1989), McDermott and Hawkesworth (1991), and J.M. Hergt (unpubl. data). Analytical uncertainties are similar to the size of symbols used.

\section{Mantle Dynamics: The Link Between Slab Rollback and Seafloor Spreading}

That the older Lau Basin crust reflects the existence of a Pacific MORB mantle source beneath this region is clear; however, it is not clear if this has always been the case or whether some trench reorientation in the past succeeded in trapping Pacific material there. What- ever the cause, at least at the earliest stages of Lau Basin formation recorded by the backarc magmas from Site 834 , the underlying asthenosphere was like Pacific MORB (see also Hergt and Nilsson, this volume).

The initiation of backarc opening may have been triggered by the tear in the Pacific Plate to the north of the arc system (now southwest of Samoa). Release of the "suction" force between the hinge of the 


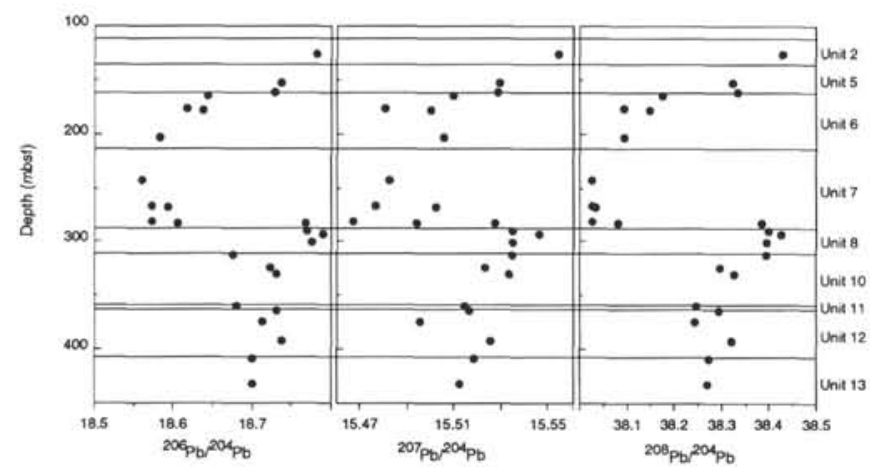

Figure 4. Plot of the Pb-isotope data vs. depth for samples from Site 834. Although somewhat scattered in the case of ${ }^{207} \mathrm{~Pb} /{ }^{204} \mathrm{~Pb}$, the cycle of ${ }^{206} \mathrm{~Pb} /{ }^{204} \mathrm{~Pb}$ and ${ }^{208} \mathrm{~Pb} /{ }^{204} \mathrm{~Pb}$ values reaching extremes in Units 2,7 , and 8 is clear. See text for discussion.

downgoing slab and the sub-forearc wedge would enable rollback of the slab in this region, and, once initiated, this would progress southward. Rollback would be greatest in the north, causing a clockwise rotation of the trench, an increase in the subduction rate, and a shallowing of the slab dip. These features are consistent with observations reported from other studies (e.g., Hynes and Mott, 1985; Giardini and Woodhouse, 1986; Parson, Hawkins, Allan, et al., 1992).

We propose that rollback of the slab induced eastward asthenospheric advection into the sub-arc/basin system, and that this carried with it the boundary between Pacific mantle underlying the original arc and the convecting Indian Ocean asthenosphere farther to the west (Fig. 5). This compositional interface between Indian and Pacific mantle may have been similar to that described by Klein et al. (1988) for the Australian-Antarctic discordance. Whether magmas were derived from Indian or Pacific mantle will have depended on a number of factors. In the earliest stages of rifting, only Pacific asthenosphere will have underlain the evolving basin. This was the case at approximately $5.5 \mathrm{Ma}$ at Site 834, and it is presumably still the case south of the Valu Fa Ridge. With increased slab rollback, however, Indian asthenosphere will have been drawn into the sub-basin mantle. This was accompanied by increased crustal thinning, to the point where true seafloor spreading was initiated.

The link between slab rollback and seafloor spreading is very important, as it appears to be a key requirement for the appearance of Indian Ocean signatures in the erupted magmas. It is possible that the initial position of the propagating ELSC ridge tip relative to the Tonga Ridge marks the boundary between Indian and Pacific asthenosphere components. This would explain the correlation between the propagation of true seafloor spreading and the appearance of the Indian mantle signatures in the erupted basalts.

The alternative is that the location of the Indian-Pacific mantle boundary may lie slightly east of the propagating ridge tip, and that appearance of Indian Ocean signatures merely reflects the depth or dynamics of melting. A number of reasons can be proposed as to why the initiation of seafloor spreading might generate magmas that preferentially tap the underlying Indian mantle. For example, we do not know how thin the layer of Pacific mantle becomes during extension before seafloor spreading, or whether it can be destroyed wherever it is penetrated by upwelling Indian Ocean asthenosphere at established spreading centers. It is also possible that melt depletion during the horst-and-graben-style extension leaves the trapped residual Pacific mantle unable to contribute significantly to magmas derived from the underlying Indian asthenosphere. A third possibility is that the depth of melt initiation is increased with seafloor spreading, producing magmas dominated by material from the Indian Ocean source region. Whatever the cause, (1) the appearance of melts derived from Indian Ocean asthenosphere is synchronous with propagation of seafloor spreading,
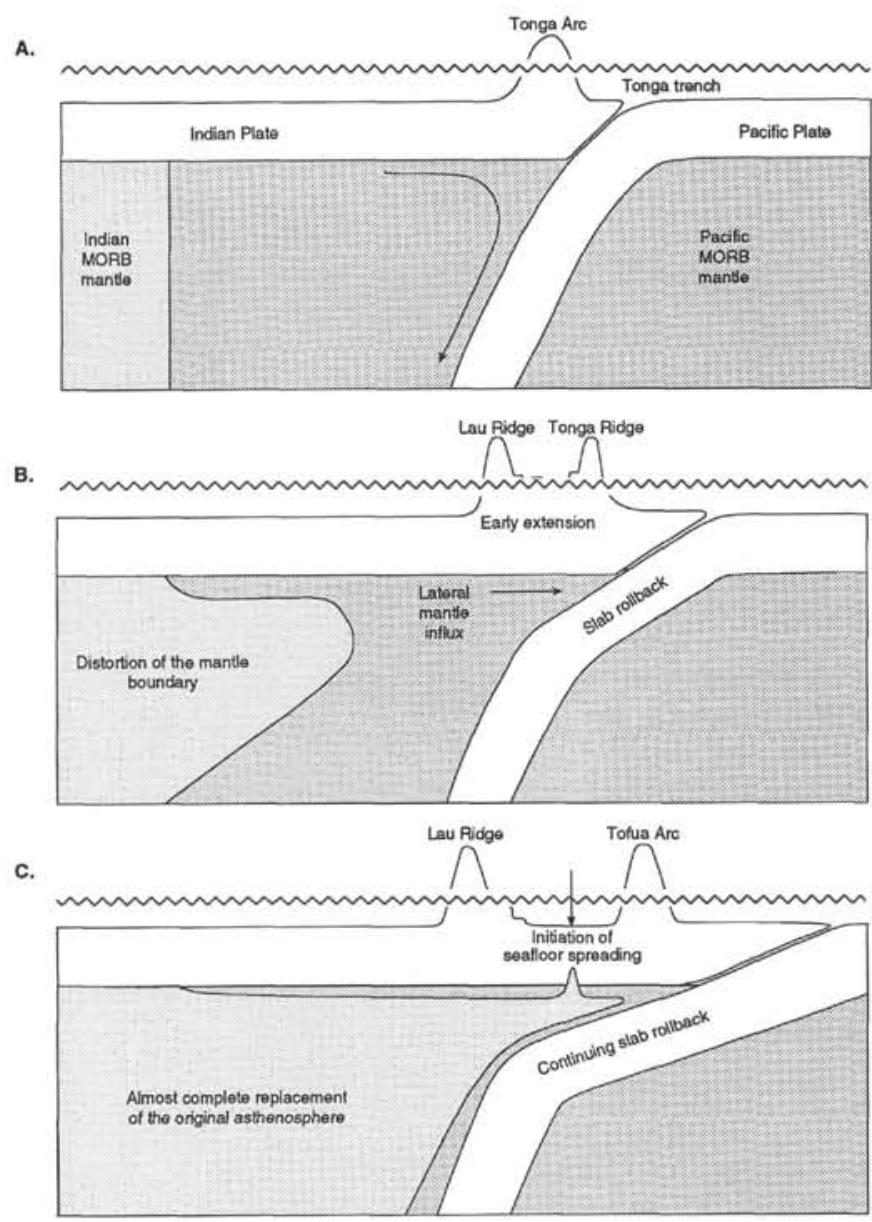

Figure 5. Illustration of the slab rollback-induced mantle dynamics in the evolving Lau Basin. A. Before extension, Pacific asthenosphere underlay the active arc. At some distance off to the west, a boundary existed between the convecting Indian asthenosphere and Pacific mantle. B. With the onset of slab rollback, an influx of mantle was laterally drawn into the sub-arc wedge. This distorted the boundary between the different asthenospheric source regions, and extension occurred in (or adjacent to) the overlying arc. C. With the continuation of rollback, circulation of Indian MORB mantle beneath the developing backarc basin progressed. Close to the mechanical boundary layer, Pacific compositions probably persisted, and, although extension was limited (e.g., horst-and-graben block faulting), only this material was able to upwell and melt. With the onset of true seafloor spreading, however, the deeper (now Indian Ocean) mantle was drawn to the surface, bringing a change in the chemistry of the erupting magmas. Convection of the upwelling mantle at the spreading center (in addition to continued slab rollback-induced advection) carried Indian Ocean asthenosphere into the sub-arc mantle wedge, so that as migration of the propagating spreading-ridge tip continued southward, the chemistries of both the arc and backarc were profoundly influenced.

so that (2) the Indian Ocean mantle must either already be available for melting, or arrive at the same time as the propagator.

According to the tectonic model of Parson and Hawkins (this volume), the ridge formed by the propagator is still in evidence as the Eastern Lau Spreading Center (ELSC) that we observe today, and the propagator tip itself is now located at the Valu Fa Ridge. It is also noteworthy, then, that this is the only segment of the modern Lau Basin spreading systems that produces magmas with influences from both Pacific and Indian ocean Pb-isotopic signatures. The CLSC and ELSC Pb compositions are entirely consistent with an Indian Ocean type of mantle source as far south as $20.5^{\circ} \mathrm{S}$ (Loock et al., 1990; J.M. Hergt, unpubl. data); however, at the Valu Fa Ridge, the composition 
changes to one with an influence from Pacific MORB $\mathrm{Pb}$ (Loock et al., 1990). These authors interpreted the presence of a Pacific $\mathrm{Pb}$ signature either to a flux of $\mathrm{Pb}$ from the downgoing Pacific Plate, or to the existence of Pacific MORB in the source of the Valu Fa magmas. Figure 3 shows the $\mathrm{Pb}$ composition of the Valu Fa basalts relative to the two Tongan fields and the new data for the Lau Basin. The Valu Fa data plot between the two backarc arrays (and the two arc fields). We suggest that this segment of the ridge is the site where magmatism is still transitional between that triggered by the horst-and-grabenstyle extension tapping the Pacific mantle source and the true seafloor spreading initiating the upwelling of Indian MORB at the present day. In this way, the Valu Fa magmas represent mixtures that would have plotted on the trends defined by Sites 834 and 839 had it not been for the influence of the underlying Indian Ocean mantle.

\section{Magmagenesis at the Individual Backarc Sites}

Unlike arc magmatism, which derives its unusual chemical features from a slab-derived flux of elements and processes operating on the wedge, the compositions of backarc rocks may result from a variety of different processes. Traces of arc-like characteristics (e.g., low $\mathrm{Ce} / \mathrm{Pb}$, elevated $\mathrm{Sr}$ and $\mathrm{Pb}$ isotopic ratios relative to relevant MORB), might be the result of (1) magma mixing between upwelling mantle and the erupting arc during early stages of extension, (2) the infiltration of a "flux" of certain elements into the mantle source region of back arc magmas (i.e., similar to that beneath arcs but to a far lesser extent), or (3) contamination by overlying arc lithosphere during upwelling associated with extension.

We have made the observation that Sites 834 and 839 within the old extended arc crust were influenced by Pacific mantle, whereas Sites 836 and 837 are consistent with an underlying mantle more similar to Indian Ocean asthenosphere. In detail, Site 834 spans a considerable range of $\mathrm{Pb}$ and $\mathrm{Sr}$ compositions, and Hergt and Nilsson (this volume) propose that these magmas represent mixtures between mafic Pacific MORB magmas and coeval arc magmas tapped from the extending crust. The observed variation in isotopic compositions would require contributions from the arc magma of between $0 \%$ (Unit
7) and $~ 50 \%$ (Units 2 and 8 ). The major and trace element chemistries are broadly consistent with this interpretation, although subsequent fractional crystallization has blurred the original mixing trends in most cases. In contrast, samples from Site 839 show very little isotopic variation, and, from their general chemistry, Ewart et al. (this volume) suggest that these rocks comprise part of an abandoned arc construct rather than new "backarc" crust. This contrast in petrogenetic interpretations is clearest from the incompatible element abundance patterns, and a comparison between samples from Sites 834 and 839 is given in Figure 6 (data listed in Table 2). The observation that some samples from Site 834 plot at slightly more radiogenic $\mathrm{Pb}$ values compared with Site 839 probably indicates a small variation in the $\mathrm{Pb}$ composition of the arc end-member (such as the differences in magmas from the Tofua Arc, excluding 'Ata, Tafahi, and Niuatoputapu). Hergt and Nilsson (this volume) suggested that an arc endmember similar in composition to 'Eua could explain the chemical variations in rocks from Site 834, whereas the Site 839 rocks are more closely matched by the single analysis from 'Ata and the small field of data for arc magmas from Site 841 (Bloomer et al., this volume).

The major dilemma with interpretations based on samples recovered from Sites 835 through 838 is that little or no basement was recovered from these localities. That is, either the material available may not truly be in situ (e.g., the hyaloclastite of Site 838), or the minimal depth of penetration into in-situ flows means that little chemical variation has been documented at these sites. Therefore, although the lack of chemical variation may be real, it may also be an artifact of the poor sampling at these sites.

As noted previously, the exact location of Site 835 relative to the southward-propagating ridge tip is unclear, and as such, the tectonic environment at the time of magmatism is open to speculation. The samples from Site 835 are very similar in their $\mathrm{Pb}$ composition to basalts from Sites 839 and 841 , and this might indicate the dominance of $\mathrm{Pb}$ from the original arc in the petrogenesis of these rocks. This is less pronounced in the $\mathrm{Sr}$-isotopic signatures, and the samples from Site 835 are closer in composition to the most radiogenic samples of Site 834 than arc rocks from Site 839. Trace element abundance patterns for the samples from Site 835 show significant deviations

Table 2. Major and trace element data for samples from Sites $\mathbf{8 3 5}, \mathbf{8 3 6}, \mathbf{8 3 7}$, and 838 .

\begin{tabular}{|c|c|c|c|c|c|c|c|c|c|c|c|c|c|c|c|c|c|c|c|}
\hline $\begin{array}{l}\text { Core, section, } \\
\text { interval }(\mathrm{cm})\end{array}$ & $\begin{array}{l}\text { Unit or } \\
\text { subunit }\end{array}$ & $\mathrm{SiO}_{2}$ & $\mathrm{TiO}_{2}$ & $\mathrm{Al}_{2} \mathrm{O}_{3}$ & $\mathrm{FeO}$ & $\mathrm{MnO}$ & $\mathrm{MgO}$ & $\mathrm{CaO}$ & $\mathrm{Na}_{2} \mathrm{O}$ & $\mathrm{K}_{2} \mathrm{O}$ & $\mathrm{P}_{2} \mathrm{O}_{5}$ & $\mathrm{Rb}$ & $\mathrm{Sr}$ & $\mathrm{Y}$ & $\mathrm{Zr}$ & $\mathrm{Nb}$ & Cs & $\mathrm{Ba}$ & $\mathrm{La}$ \\
\hline \multicolumn{20}{|l|}{$135-835 \mathrm{~B}$} \\
\hline $3 R-1,123-127$ & 1 & 52.12 & 1.04 & 15.66 & 10.33 & 0.15 & 6.57 & 11.23 & 2.59 & 0.21 & 0.10 & 3.37 & 138 & 23.3 & 39.0 & 0.56 & 0.07 & 36.8 & 1.81 \\
\hline $3 R-2,0-4$ & 1 & 52.13 & 1.01 & 15.76 & 10.38 & 0.14 & 6.45 & 11.31 & 2.55 & 0.20 & 0.08 & 3.53 & 138 & 23.9 & 40.4 & 0.59 & 0.07 & 41.0 & 1.94 \\
\hline $4 \mathrm{R}-1,73-78$ & 1 & 52.41 & 1.61 & 15.48 & 11.61 & 0.24 & 4.97 & 9.51 & 3.75 & 0.27 & 0.15 & 3.54 & 144 & 25.9 & 42.6 & 0.61 & 0.07 & 40.1 & 2.21 \\
\hline $5 \mathrm{R}-1,14-21$ & 1 & 52.04 & 1.11 & 15.83 & 10.27 & 0.19 & 6.51 & 11.26 & 2.51 & 0.18 & 0.10 & 3.36 & 141 & 24.4 & 41.1 & 0.54 & 0.07 & 37.2 & 1.94 \\
\hline $7 R-2,75-84$ & 1 & & & & & & & & & & & 1.59 & 137 & 20.6 & 34.4 & 0.48 & 0.02 & 28.2 & 1.61 \\
\hline $7 \mathrm{R}-3,135-140$ & 1 & 52.17 & 0.99 & 15.82 & 10.23 & 0.16 & 6.42 & 11.24 & 2.64 & 0.21 & 0.12 & 3.48 & 137 & 24.2 & 41.1 & 0.51 & 0.08 & 38.3 & 1.87 \\
\hline \multicolumn{20}{|l|}{ 135-836A- } \\
\hline $3 \mathrm{H}-3,23-24$ & 1 & 55.53 & 1.22 & 15.26 & 11.69 & 0.19 & 4.13 & 8.45 & 3.13 & 0.24 & 0.15 & 3.81 & 148 & 35.0 & 70.2 & 0.96 & 0.12 & 52.6 & 2.96 \\
\hline $3 \mathrm{H}-3,30-95$ & 1 & 55.43 & 1.26 & 14.92 & 12.49 & 0.12 & 3.84 & 8.36 & 3.18 & 0.25 & 0.15 & 5.00 & 163 & 38.0 & 76.5 & 1.09 & 0.17 & 55.1 & 2.99 \\
\hline $3 \mathrm{H}-3,33-43$ & 1 & & & & & & & & & & & 4.20 & 159 & 35.5 & 74.7 & 1.04 & 0.12 & 54.3 & 2.71 \\
\hline $3 \mathrm{H}-4,53-110$ & 2 & 57.68 & 1.11 & 14.81 & 11.39 & 0.23 & 3.24 & 7.66 & 3.45 & 0.29 & 0.15 & 4.02 & 151 & 40.2 & 83.5 & 1.22 & 0.12 & 65.1 & 3.35 \\
\hline $3 \mathrm{H}-4,88-100$ & 2 & & & & & & & & & & & 4.21 & 153 & 37.0 & 78.0 & 1.22 & 0.14 & 65.1 & 3.15 \\
\hline $3 \mathrm{H}-\mathrm{CC}, 0-7$ & 3 & 49.51 & 0.84 & 15.83 & 9.30 & 0.20 & 8.31 & 13.59 & 2.30 & 0.06 & 0.05 & 0.96 & 163 & 20.2 & 37.5 & 0.41 & 0.02 & 9.2 & 1.63 \\
\hline $9 X-1,54-58$ & 4 & & & & & & & & & & & 0.53 & 154 & 19.4 & 38.2 & 0.43 & 0.01 & 10.9 & 1.55 \\
\hline $9 X-2,16-24$ & 4 & & & & & & & & & & & 2.15 & 268 & 19.9 & 39.2 & 0.42 & 0.17 & 9.2 & 1.61 \\
\hline \multicolumn{20}{|l|}{$135-836 \mathrm{~B}-$} \\
\hline $3 R-1,47-52$ & $4 a$ & 49.47 & 0.88 & 15.84 & 9.18 & 0.16 & 8.41 & 13.65 & 2.28 & 0.06 & 0.08 & 2.23 & 168 & 19.6 & 37.6 & 0.46 & 0.09 & 14.1 & 1.65 \\
\hline $5 R-2,65-74$ & $4 b$ & & & & & & & & & & & 0.62 & 148 & 17.8 & 33.2 & 0.35 & 0.01 & 6.7 & 1.30 \\
\hline $6 \mathrm{R}-2,20-25$ & $4 \mathrm{~b}$ & & & & & & & & & & & 0.61 & 151 & 16.5 & 30.6 & 0.31 & 0.01 & 5.8 & 1.29 \\
\hline $7 R-2,62-67$ & 5 & & & & & & & & & & & 4.36 & 159 & 27.8 & 53.4 & 1.14 & 0.10 & 39.8 & 2.65 \\
\hline $9 \mathrm{M}-1,97-102$ & & 53.01 & 1.09 & 15.04 & 11.64 & 0.26 & 5.77 & 10.15 & 2.59 & 0.26 & 0.19 & 3.65 & 154 & 27.4 & 52.6 & 1.05 & 0.07 & 46.2 & 2.71 \\
\hline \multicolumn{20}{|l|}{$135-837 \mathrm{~B}-$} \\
\hline $2 \mathrm{R}-1,59-63$ & 1 & & & & & & & & & & & 10.29 & 166 & 40.9 & 75.5 & 1.89 & 0.14 & 63.6 & 3.88 \\
\hline $4 \mathrm{R}-1,101-109$ & $i$ & & & & & & & & & & & 8.99 & 173 & 40.5 & 78.0 & 1.94 & 0.14 & 63.0 & 3.93 \\
\hline $5 R-1,86-92$ & 1 & & & & & & & & & & & 9.73 & 176 & 40.8 & 78.7 & 2.02 & 0.13 & 64.2 & 4.06 \\
\hline \multicolumn{20}{|l|}{$135-838 \mathrm{~A}-$} \\
\hline $20 \mathrm{H}-1,50-110$ & 1 & 72.41 & 0.76 & 12.27 & 5.69 & 0.21 & 0.76 & 3.78 & 3.61 & 0.31 & 0.19 & 3.28 & 182 & 50.6 & 75.9 & 0.51 & 0.23 & 188 & 2.48 \\
\hline
\end{tabular}

Note: Data for the other samples presented in Table 1 are located in Hergt and Nilsson, Ewart et al., and Bloomer et al. (all in this volume). 
from MORB, and parallel the normalized abundance patterns for samples from the Valu Fa Ridge (Fig. 7A). We interpret this as possible evidence for arc magmatism adjacent to Site 835 , similar to the current proximity of 'Ata relative to the Valu Fa Ridge. Just as is the case in this modern example, the upwelling mantle appears to have had closer affinities with Pacific MORB than with MORB from the Indian Ocean. If magmatism at Site 835 occurred 0.5 m.y. after the arrival of the propagating ridge tip, then the proximity of the spreading ridge did not control the MORB chemistry of these magmas. This interpretation for the magmatism at Site 835 is highly speculative, because of the recovery of basalts with only a single composition (only a $\sim 25$ - $\mathrm{m}$ depth was drilled into basement).

In the case of basalts from Site 837 , magmatism is thought to have occurred at, or close to, the location of the propagating ridge tip. From the tectonic setting of eruptions at Site 837, it would appear that the Valu Fa Ridge is now what Site 837 was approximately 2 m.y. ago. That is, at both localities, the propagator tip separated old extended arc crust from the (still active?) Tonga Ridge. Therefore, we might expect rocks from Site 837 to have signatures even more similar to those observed at the Valu Fa Ridge than noted at Site 835. The Srand Nd-isotopic compositions are very similar in the samples from Site 837 and the Valu Fa Ridge, which supports this possibility, as are the trace element signatures, which are also very closely matched (Fig. 7B; only slightly lower $\mathrm{Ba} / \mathrm{Rb}$ is apparent in the magmas from Site 837 compared with the Valu Fa Ridge). In contrast, the $\mathrm{Pb}$ compositions are quite different, and the magmas from Site 837 plot within the field for the modern Tofua Arc (excluding 'Ata, Tafahi, and Niuatoputapu).

Clearly, the $\mathrm{Pb}$ compositions of magmas from Site 837 have been more strongly influenced by Indian MORB mantle, compared with melts produced at the Valu Fa Ridge. Given the limited chemical variation at Site 837 (again, only a single geochemical unit encountered in the $35 \mathrm{~m}$ of basement drilled), the reason for this must remain speculative. We can suggest that, just as the Valu Fa is adjacent to the active island of 'Ata, so too might Site 837 have been close to an island from the arc. In the case of Site 837 , however, the $\mathrm{Pb}$ composition of the arc magmas would need to have been very similar in composition to those of the modern Tofua Arc rocks (excluding the islands of 'Ata, Tafahi, and Niuatoputapu). The observation from the Valu Fa Ridge is that the $\mathrm{Pb}$-isotope composition can be almost identical to that of the adjacent arc, and this could explain the similarity between Site 837 and the Tofua magmas. Although this is not unreasonable, the $\mathrm{Sr}$ and Nd data from the Site 837 rocks do not similarly plot close to the modern Tofua Arc field. This perhaps results from the greater difference between the $\mathrm{Pb}$ contents of the two components (which permits a greater arc influence on the $\mathrm{Pb}$ compositions) relative to their $\mathrm{Sr}$ and Nd concentrations.

Basement was not intersected at Site 838; however, two thick hyaloclastite layers were recovered among the turbiditic sequences. The age of these units is approximately $2 \mathrm{Ma}(>1.8 \mathrm{Ma}$, judging from paleontological evidence; see Parson, Hawkins, Allan, et al., 1992), which is similar to the time of magmatism at both Sites 837 and 839 . The one analysis for Site 838 shown in the $\mathrm{Sr}-\mathrm{Nd}$ and $\mathrm{Pb}$ diagrams is for a single piece of rhyolite glass picked from one of these two intervals. It displays the most radiogenic $\mathrm{Pb}$ compositions yet reported for the Lau Basin and almost certainly represents an arc derivative.

The remaining locality drilled in the backarc basin, Site 836, contained the youngest of the basement samples recovered during Leg 135 (magmatism $\sim 1 \mathrm{Ma}$ ), which most closely resemble rocks dredged from the ML. The uppermost units do not represent true basement but occur as basalt gravels intercalated with sediment. These are the most radiogenic of the Site 836 samples shown on the $\mathrm{Pb}$-isotope diagrams, whereas true basement (Units 4 and 5) plots within the field for ML. The more radiogenic samples are very similar in composition to the rocks from Site 837 and share very similar normalized trace element abundances (Fig. 8A). In contrast, the basement samples have relatively smoother trace element abundance patterns and show closer affinities with ML (Fig. 8B).

In summary, eruptions at Site 834 represent mixtures of arc and Pacific MORB magmas, whereas material from Sites 838 and 839 were probably erupted from true arc edifices. Sites 835 and 837 were close to the predicted location of the propagating ridge tip at the time of magmatism, and the magmas from these sites show similarities with samples dredged from the Valu Fa Ridge. The rocks from Sites

Table 2 (continued).

\begin{tabular}{|c|c|c|c|c|c|c|c|c|c|c|c|c|c|c|c|c|c|c|c|}
\hline $\mathrm{Ce}$ & $\mathrm{Pr}$ & $\mathrm{Nd}$ & $\mathrm{Sm}$ & $\mathrm{Eu}$ & Gd & $\mathrm{Tb}$ & Dy & Ho & $\mathrm{Er}$ & $\mathrm{Tm}$ & $\mathrm{Yb}$ & $\mathrm{Lu}$ & $\mathrm{Hf}$ & $\mathrm{Ta}$ & w & $\mathrm{Tl}$ & $\mathrm{Pb}$ & Th & $\mathrm{U}$ \\
\hline 5.30 & 0.86 & 5.54 & 2.01 & 0.83 & 3.10 & 0.48 & 3.67 & 0.74 & 2.31 & 0.39 & 2.22 & 0.37 & 1.26 & 0.28 & 0.03 & 0.07 & 0.61 & 0.13 & 0.05 \\
\hline 5.71 & 1.02 & 5.44 & 2.25 & 0.88 & 3.25 & 0.58 & 3.87 & 0.82 & 2.51 & 0.42 & 2.25 & 0.43 & 1.35 & 0.53 & 0.06 & 0.12 & 0.66 & 0.14 & 0.07 \\
\hline 5.76 & 1.01 & 5.53 & 2.33 & 0.87 & 3.48 & 0.45 & 4.03 & 0.91 & 2.53 & 0.38 & 2.31 & 0.44 & 1.40 & 0.09 & 0.03 & 0.05 & 0.64 & 0.15 & 0.09 \\
\hline 5.39 & 0.89 & 5.50 & 2.09 & 0.87 & 3.30 & 0.46 & 3.78 & 0.74 & 2.40 & 0.37 & 2.26 & 0.41 & 1.28 & 0.26 & 0.04 & 0.06 & 0.60 & 0.13 & 0.06 \\
\hline 4.42 & 0.76 & 4.72 & 1.79 & 0.77 & 2.70 & 0.53 & 3.28 & 0.76 & 2.14 & 0.31 & 1.91 & 0.39 & 1.02 & 0.04 & 0.06 & 0.04 & 0.79 & 0.12 & 0.13 \\
\hline 5.47 & 0.87 & 5.68 & 2.02 & 0.87 & 3.09 & 0.50 & 3.71 & 0.83 & 2.43 & 0.34 & 2.37 & 0.43 & 1.30 & 0.08 & 0.04 & 0.05 & 0.66 & 0.20 & 0.08 \\
\hline 8.44 & 1.50 & 8.46 & 3.14 & 1.23 & 4.68 & 0.71 & 5.54 & 1.35 & 3.61 & 0.60 & 3.51 & 0.67 & 2.13 & 0.19 & 0.04 & 0.10 & 1.00 & 0.19 & 0.09 \\
\hline 8.55 & 1.45 & 8.73 & 3.27 & 1.19 & 4.99 & 0.75 & 5.95 & 1.19 & 3.56 & 0.54 & 3.82 & 0.61 & 2.11 & 0.13 & 0.06 & 0.10 & 1.03 & 0.19 & 0.13 \\
\hline 8.11 & 1.36 & 8.37 & 3.09 & 1.11 & 4.87 & 0.85 & 5.40 & 1.24 & 3.77 & 0.52 & 3.36 & 0.73 & 2.02 & 0.08 & 0.03 & 0.10 & 1.23 & 0.16 & 0.09 \\
\hline 9.51 & 1.59 & 9.33 & 3.33 & 1.28 & 5.30 & 0.75 & 6.14 & 1.30 & 3.99 & 0.61 & 3.82 & 0.68 & 2.47 & 0.23 & 0.09 & 0.16 & 1.15 & 0.23 & 0.12 \\
\hline 9.11 & 1.53 & 8.90 & 3.42 & 1.18 & 4.80 & 0.88 & 5.67 & 1.23 & 4.00 & 0.60 & 3.60 & 0.78 & 2.19 & 0.12 & 0.10 & 0.37 & 1.36 & 0.23 & 0.13 \\
\hline 4.96 & 0.81 & 5.01 & 1.91 & 0.83 & 2.63 & 0.43 & 3.09 & 0.73 & 1.94 & 0.31 & 1.87 & 0.32 & 1.00 & 0.12 & 0.05 & 0.10 & 0.35 & 0.05 & 0.02 \\
\hline 5.10 & 0.86 & 5.10 & 1.76 & 0.79 & 2.52 & 0.52 & 3.06 & 0.65 & 2.05 & 0.33 & 1.69 & 0.30 & 1.07 & 0.10 & 0.03 & 0.08 & 0.24 & 0.06 & 0.13 \\
\hline 5.28 & 0.85 & 5.28 & 1.93 & 0.75 & 2.72 & $0 . S 0$ & 3.17 & 0.64 & 2.07 & 0.36 & 1.87 & 0.33 & 1.01 & 0.10 & 0.03 & 0.07 & 0.20 & 0.06 & 0.10 \\
\hline 4.93 & 0.79 & 4.86 & 1.90 & 0.74 & 2.63 & 0.38 & 3.18 & 0.70 & 1.97 & 0.30 & 1.85 & 0.32 & 1.07 & 0.04 & 0.33 & 0.10 & 0.41 & 0.05 & 0.02 \\
\hline 4.23 & 0.71 & 4.34 & 1.70 & 0.63 & 2.23 & 0.45 & 2.80 & 0.59 & 1.85 & 0.27 & 1.66 & 0.37 & 0.85 & 0.05 & 0.02 & 0.08 & 0.65 & 5.05 & 0.05 \\
\hline 3.98 & 0.70 & 5.63 & 1.51 & 0.72 & 2.34 & 0.39 & 2.66 & 0.61 & 1.69 & 0.24 & 1.51 & 0.26 & 0.84 & 0.05 & 0.05 & 0.04 & 0.66 & 0.05 & 0.03 \\
\hline 7.70 & 1.25 & 7.31 & 2.70 & 0.95 & 3.71 & 0.71 & 4.47 & 1.06 & 3.02 & 0.46 & 2.63 & 0.52 & 1.62 & 0.13 & 0.05 & 0.08 & 0.93 & 0.21 & 0.09 \\
\hline 7.22 & 1.13 & 6.75 & 2.60 & 0.89 & 3.80 & 0.61 & 4.37 & 0.93 & 2.77 & 0.44 & 2.70 & 0.47 & 1.43 & 0.27 & 0.05 & 0.09 & 0.78 & 0.19 & 0.09 \\
\hline 10.8 & 1.78 & 9.95 & 3.70 & 1.29 & 5.35 & 0.77 & 6.29 & 1.35 & 4.03 & 0.72 & 5.09 & 0.75 & 2.37 & 0.21 & 0.06 & 0.53 & 1.02 & 0.33 & 0.12 \\
\hline 11.1 & 1.73 & 10.34 & 3.66 & 1.33 & 5.33 & 1.01 & 6.26 & 1.36 & 4.18 & 0.65 & 3.82 & 0.74 & 2.36 & 0.13 & 0.05 & 0.06 & 1.19 & 0.33 & 0.19 \\
\hline 10.8 & 1.75 & 10.45 & 3.69 & 1.37 & 5.45 & 0.99 & 6.24 & 1.33 & 4.10 & 0.62 & 3.88 & 0.72 & 2.27 & 0.16 & 0.05 & 0.15 & 1.11 & 0.32 & 0.35 \\
\hline 8.03 & 1.58 & 9.70 & 4.28 & 1.55 & 7.11 & 1.06 & 8.22 & 1.76 & 5.20 & 0.80 & 4.98 & 0.88 & 2.53 & 0.26 & 0.21 & 0.06 & 2.19 & 0.10 & 0.10 \\
\hline
\end{tabular}




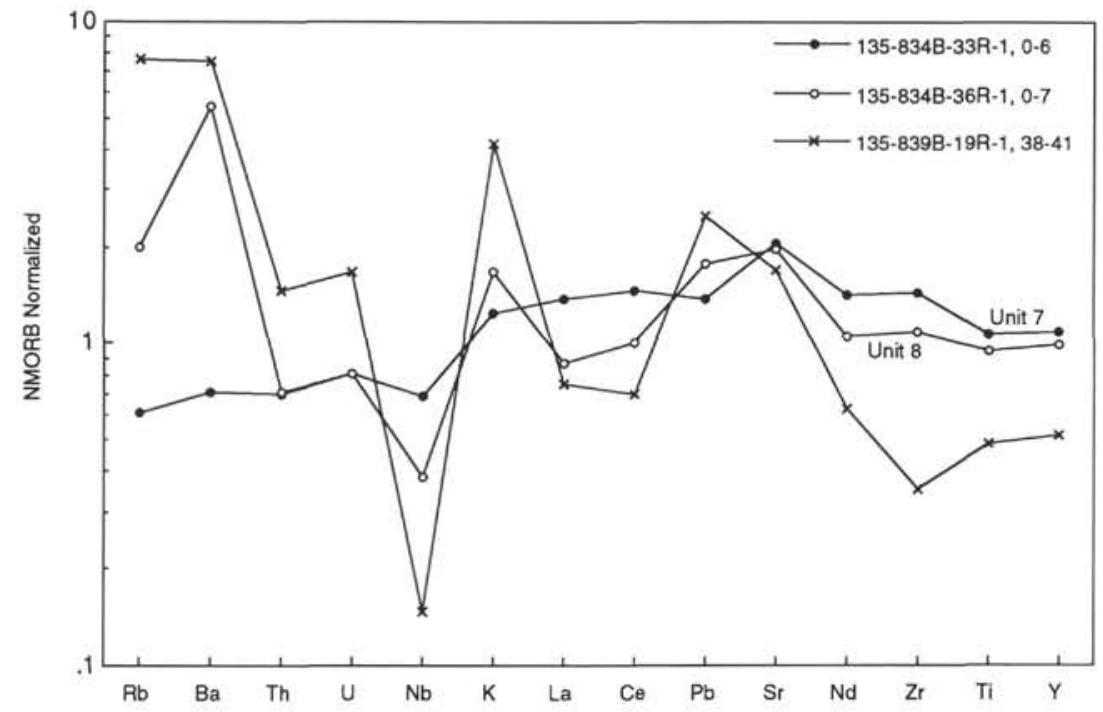

Figure 6. NMORB-normalized trace element patterns for the most and least radiogenic samples from Site 834 (Units 8 and 7, respectively), compared with a trace element composition typical of rocks from Site 839. Data from Table 2; normalizing values are from Sun and McDonough (1989).

835 and 837 , therefore, might represent backarc basalts erupted in close proximity to active arc magmatism. In keeping with the location of Site 836 within crust generated by true seafloor spreading, rocks from this site are likely to represent magmas erupted at the newly formed spreading center, and most closely resemble basalts from the modern spreading ridges.

\section{Mantle Dynamics: Influence on the Evolving Arc}

The effective removal of Pacific MORB mantle, and its replacement with Indian Ocean asthenosphere beneath the backarc basin, has also had a profound influence on the arc magmatism. As noted earlier, the active Tofua Arc extends from the islands of Tafahi and Niuatoputapu in the north $\left(\sim 15.5^{\circ} \mathrm{S}\right)$ to 'Ata $\left(\sim 22^{\circ} \mathrm{S}\right)$ close to the Valu Fa Ridge. In terms of their $\mathrm{Pb}$-isotopic compositions, all of the arc rocks from islands between these two extremes plot in a tight cluster on extension of the Indian MORB field. In fact, these arc data plot at the end of the trend defined by the results from Sites 836 and 837 . Two exceptions to this tight group are found in the limited number of data for the northernmost islands: the data for Tafahi and Niuatoputapu are displaced to significantly more radiogenic $\mathrm{Pb}$ compositions, with even higher ${ }^{206} \mathrm{~Pb} /{ }^{204} \mathrm{~Pb}$ ratios compared with some Pacific sediments documented in the literature (e.g., Sun, 1980; Ben Othman et al., 1989).

In our earlier discussion regarding the advection of Indian Ocean asthenosphere into the sub-basin mantle, we noted that the appearance of Indian MORB-like signatures in magmas was coincident with the propagation of seafloor spreading (Fig. 5). Clearly, the upwelling Indian mantle giving rise to these basalts will migrate laterally beneath the zone of spreading. Given the close proximity of the active arc to the migrating ridge tip, the arc mantle wedge is unlikely to escape the effects of this influx of Indian Ocean mantle material. It is intriguing to note that the islands of Tafahi and Niuatoputapu are located too far north to have been influenced by the southward migration of the ELSC into the Lau Basin and the influx of Indian MORB that accompanied this process (Fig. 1).

Perhaps, in some respects, these northernmost islands are examples of the "original arc" composition, as compared with the islands farther south that have had their underlying wedge replaced by new asthenospheric material. This might also explain why the magmas from Tafahi and Niuatoputapu islands show such strong evidence for melt depletion in their source regions. Without replenishment, the source is only capable of producing small volumes of very depleted melts. In addition, because the sub-arc mantle has been stripped of incompatible elements, contributions from the downgoing plate dominate the trace element and isotopic signatures of these rocks (Ewart and Hawkesworth, 1987; Hawkesworth and Ellam, 1989).

The only other active island that has $\mathrm{Pb}$ compositions outside the main group is the southernmost island, 'Ata. This island lies adjacent to the Valu Fa Ridge, and it has already been suggested that this is where the magmatism is transitional and taps mixtures of Pacific mantle, Indian MORB asthenosphere, and an arc component. The $\mathrm{Pb}$ data from 'Ata are consistent with this model, as the $\mathrm{Pb}$ composition for this island appears to lie between the two arc fields and at a slightly higher ${ }^{206} \mathrm{~Pb} /{ }^{204} \mathrm{~Pb}$ composition compared with the Valu Fa rocks.

$\mathrm{The} \mathrm{Pb}$-isotope compositions of young islands located away from the influence of established seafloor spreading are similar to the values obtained for the older manifestations of arc magmatism. For example, the island of 'Eua has long been recognized as having Pb-isotope compositions close to those of Tafahi (e.g., Ewart and Hawkesworth, 1987). The Pb-isotope compositions of Tafahi, Niuatoputapu, 'Ata, 'Eua, and Sites 839 and 841 are all similar and might define a broad field for the composition of original arc magmatism. Thus, two groups of island-arc magmas would appear to be present: those that belong to the original arc (or currently erupt with these features), and the other, which typifies the majority of the modern Tofua Arc (i.e., excluding 'Ata, Tafahi, and Niuatoputapu). This does not strictly apply to the $\mathrm{Sr}$ and Nd isotopic compositions (particularly given the distinct values observed in samples from Tafahi and Niuatoputapu), because the two MORB endmembers are adjacent in $\mathrm{Sr}-\mathrm{Nd}$ isotope space. This means that, rather than separating fields into two distinct arrays as with the $\mathrm{Pb}$ compositions, displacement of the "original" arc values away from the Pacific MORB field results in their overlap with Indian MORB and the backarc basin compositions.

To summarize, we propose that the underlying Pacific MORB mantle beneath the Tonga-Lau Basin system has been systematically replaced by Indian MORB because of slab rollback and has been accompanied by the migration of the ELSC down the westward side of the Tongan Ridge. This has not only changed the backarc basin magmas from those lying on a Pacific MORB-arc mixing trend to those on an Indian MORB-arc mixing trend, but it has also resulted in the replacement of the source of the arc magmas themselves. We envisage that the substitution of the wedge occurs as the propagator migrates southward and the Tonga Ridge swings away from its original position in a clockwise rotation. The only parts of the wedge to avoid this are 

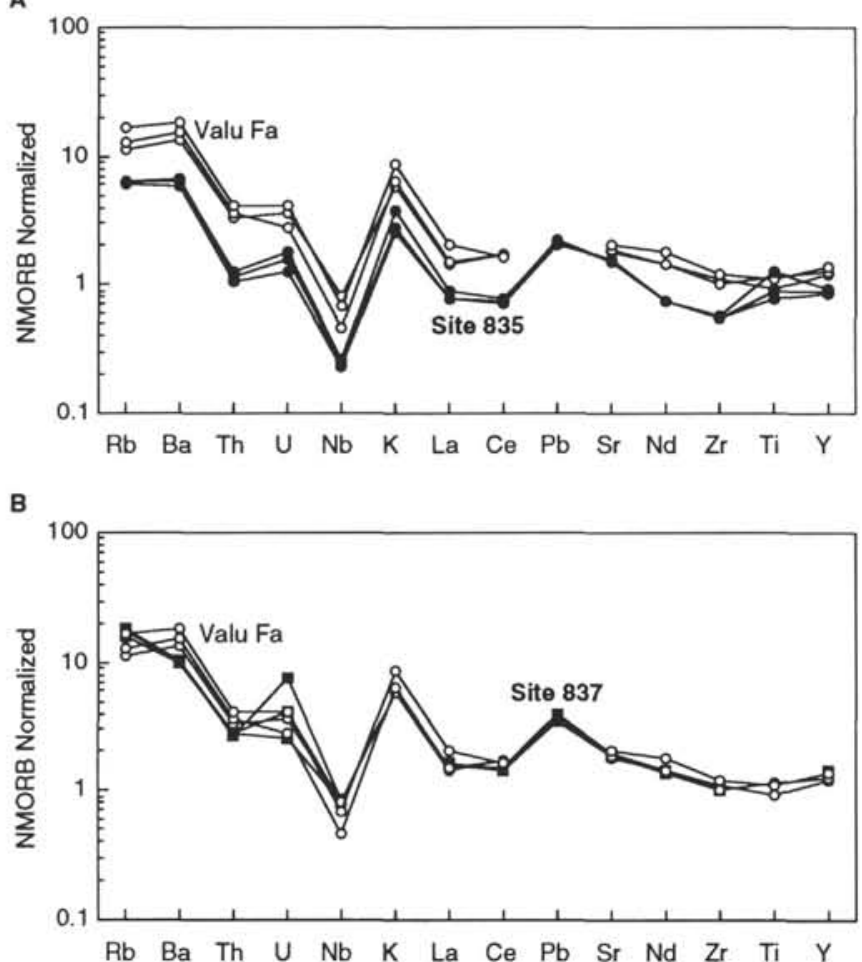

Figure 7. NMORB-normalized trace element patterns comparing Valu Fa magmas with samples from Sites 835 (A) and 837 (B). Valu Fa rocks are shown by the open circles, and the filled circles and squares denote Sites 835 and 837 , respectively (note that there are no $\mathrm{Pb}$ data for the Valu Fa rocks, and no major element data for the rocks from Site 837).

those located either north or south of the locus of the propagating ridge tip. The propagator is currently located at the Valu Fa Ridge, and this is the same place that we observe complicated mixtures of Pacific and Indian MORB and some form of arc component.

Given that the arc retains Pacific mantle features until the arrival of the propagator, the Indian-Pacific mantle boundary must lie either at, or barely east of, the ridge tip itself. We can use this information, together with the inferred trace of the propagator with time, to estimate the location of the mantle boundary during the evolution of the Lau Basin. Of course, we do not know how far west of the original Tonga Arc this mantle boundary was located before arc rupture; however, if we assume the minimum case in which the Indian-Pacific mantle boundary was immediately east of the arc (i.e., what is now the Lau Ridge; Fig. 1), then the boundary has moved eastward at least $300 \mathrm{~km}$ during block extension. Greater slab rollback toward the north has resulted in continued migration of the Indian-Pacific mantle boundary in this region, and, given the influence of Indian Ocean mantle $\mathrm{Pb}$ on the magmas erupted on Fonualei, the boundary may have traveled almost twice as far at this latitude (i.e., $\sim 600 \mathrm{~km}$ ). One difficulty in making such an estimate is that the upwelling of Indian Ocean asthenosphere beneath the ELSC will enhance the lateral flow of material toward the arc wedge and therefore increase the apparent effects of eastward advection. Nevertheless, from the isotopic data we can envisage the existence of Indian Ocean mantle beneath Fonualei and extending southsoutheast beneath the other islands of the Tofua Arc. The edge of the Indian-Pacific mantle boundary would appear to occur close to the southward propagating tip of the Valu Fa Ridge.

\section{Slab Fluxes and Arc Magmatism}

The results obtained for samples recovered from Leg 135, and their interpretation, shed new light on what might influence the composi-
A

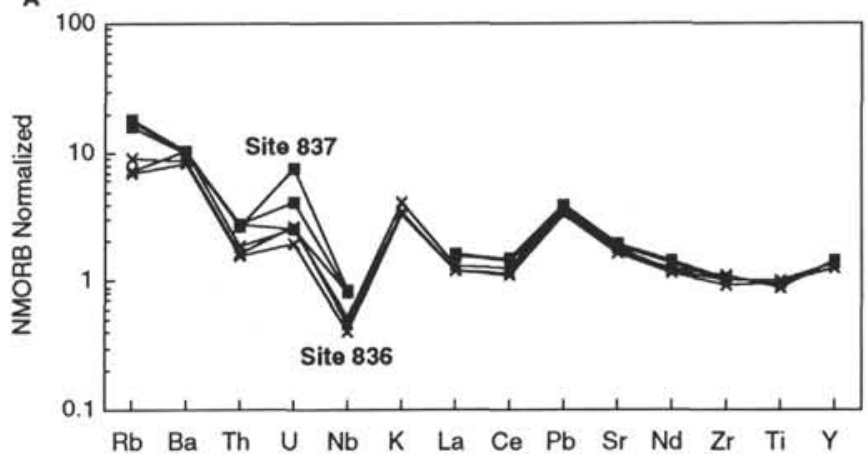

B

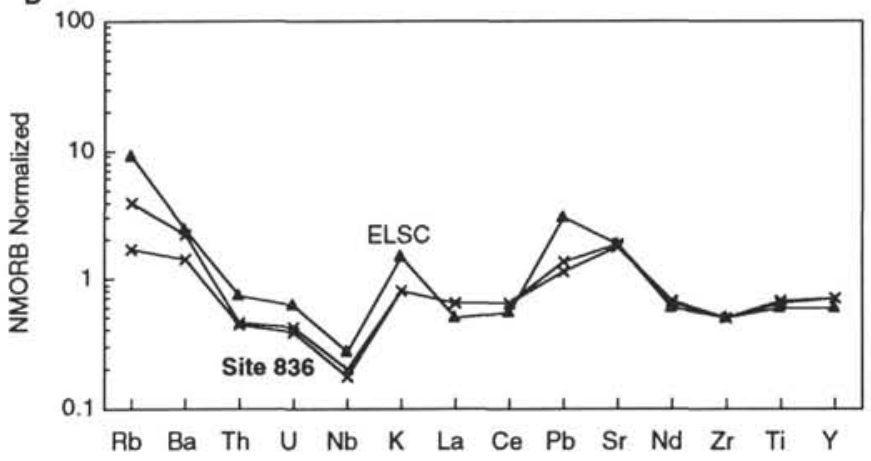

Figure 8. NMORB-normalized trace element patterns comparing the most radiogenic rocks from Site 836 (crosses) with the samples from Site 837 (filled squares) (A), and the least radiogenic samples from Site 836 (crosses) with a sample dredged from the ELSC (B) (Ernewein et al., unpubl. data).

tions of the Tongan arc rocks themselves. It is often the case that, although displaced from NMORB on isotope diagrams, arc rocks plot in homogeneous clusters. In fact, Hawkesworth, Hergt, Ellam, et al. (1991) and Hawkesworth, Hergt, McDermott, et al. (1991) noted that a number of arcs have $\mathrm{Pb}-, \mathrm{Sr}-$, and $\mathrm{Nd}$-isotope signatures that plot close to PREMA (or the PREvalent MAntle, of Zindler and Hart, 1986). Using this observation, Hawkesworth, Hergt, Ellam, et al. (1991) and Hawkesworth, Hergt, McDermott, et al. (1991) were able to place isotopic constraints on the slab-derived flux of trace elements into the mantle wedge (which is assumed to be the source of island-arc magmas). Then, by making some assumptions about the composition of the downgoing plate (i.e., proportions of fresh crust, altered MORB, and sediment), using published data for these components, and finally, by applying element mobility arguments based on work by Tatsumi et al. (1986), Hawkesworth, Hergt, Ellam, et al. (1991) and Hawkesworth, Hergt, McDermott, et al. (1991) proposed a maximum for the slab-derived flux for a number of trace elements. Their estimate for the trace element budget derived from the slab fell significantly short of the trace element enrichment observed in rocks from island arcs relative to MORB. This enabled Hawkesworth, Hergt, Ellam, et al. (1991) and Hawkesworth, Hergt, McDermott, et al. (1991) to argue that an additional process (specific to the arc environment) must be responsible for increasing the levels of certain trace elements in the source of arc magmas.

Whether this "additional process" involves the stabilization of a hydrous phase such as amphibole, or if some form of trace element scavenging is possible within the wedge was not explored by Hawkesworth, Hergt, Ellam, et al. (1991) and Hawkesworth, Hergt, McDermott, et al. (1991) in detail. More recently, investigation into the fluid/rock partitioning of trace elements suggests that fluid percolation may be the dominant method of concentrating key elements in the source of island-arc rocks (Hawkesworth et al., 1993). In this type 
of model, at least some isotopic reequilibration between the fluid and wedge is unavoidable, so that original constraints made using model isotopic compositions of the slab flux and the wedge provide minimum estimates.

One major problem in attempting to investigate the composition of the slab-derived flux is that rarely does a well-defined mixing trend occur within a suite of arc magmas. This is also generally true in the case of the Tongan arc, although significant variation does exis (Ewart and Hawkesworth, 1987). On the basis of the backarc data, we can define two asthenospheric end-members (which we can presume will have the same isotopic composition as the "uncontaminated" wedge), as well as at least one "flux" component. Convergence of the two $\mathrm{Pb}$-isotope trends defined by the backarc magmas suggests that the "flux" component might be similar, even when the wedge is replaced over time.

One test of the mantle turnover model we propose is to assume that the slab-derived flux giving rise to the arc signatures has remained effectively constant regardless of extension and backarc spreading, and to calculate whether the change in the isotopic composition of arc magmatism can be explained by substitution of the asthenospheric end-member alone. Indeed, the composition of the downgoing plate should be independent of the dynamics of the overlying wedge, and there is no reason to expect the slab flux to be linked to this process. This being the case, we can ignore the controversy regarding the size and nature of any slab-derived flux by assuming it to be a constant. This is clearly an oversimplification, and the isotopic compositions of 'Eua, 'Ata, and Sites 839 and 841 define small fields, just as do the Tofua magmas (i.e., excluding 'Ata, Niuatoputapu, and Tafahi).

To characterize the isotopic composition of the "flux," we have followed the example of Ewart and Hawkesworth (1987) by choosing data from the northernmost islands of Tafahi. These authors argued that, because the source of the magmas erupted on Tafahi is very depleted in some trace elements, the incompatible element abundances of these rocks give the closest available estimate of the slabderived flux.

On this basis, we have made the simplifying assumption that the isotopic compositions for $\mathrm{Pb}, \mathrm{Sr}$, and $\mathrm{Nd}$ in the Tafahi magmas will be dominated by the slab flux, and we have chosen appropriate values from the literature (Ewart and Hawkesworth, 1987). We can estimate the isotopic compositions of the Pacific wedge from those measured in Unit 7 from Site 834, these rocks being the closest to true MORB in the oldest backarc magmas from the Lau Basin (Hergt and Nilsson, this volume). The Indian wedge composition is best selected from the region of overlap between the ML basalts and the field for Indian MORB. Variations in ${ }^{87} \mathrm{Sr} /{ }^{86} \mathrm{Sr}$ in the arc rocks are very large and may relate to additional crustal level processes; we are aware that source depletion makes a significant difference to the isotopic signatures of the arc magmas (this being the basis for our initial assumption regarding the composition of the flux itself).

Table 3 shows the results for modeling samples from the "Old" (Pacific trend) and "Modern" (Indian trend) arc groups. The calculations were conducted as follows: (1) we assumed that the two different MORB source regions had similar $\mathrm{Pb}, \mathrm{Sr}$, and $\mathrm{Nd}$ concentrations before they mixed with the slab flux; and (2) we assumed values (as described above) for the three end-members (the Pacific and Indian MORB and the slab flux). Because the same "flux" was added to two MORB endmembers differing only in their isotopic compositions, the absolute concentrations of $\mathrm{Pb}, \mathrm{Sr}$, and $\mathrm{Nd}$ in the three end-members can be ignored. The test of our model is then reduced to a comparison between the offset from each MORB isotopic composition toward the flux; the relative proportions calculated for the flux-derived $\mathrm{Pb}, \mathrm{Sr}$, and $\mathrm{Nd}$ in the two arc types is shown in Table 3 . If the results for the two groups of arcs were very different, we would be forced to conclude that the flux itself was an important control in the production of the two distinct arc compositions. Instead, although these results are necessarily generalized, it would appear that the flux contributions required to explain the isotopic signatures observed are broadly similar in both arc groups.
Table 3. Estimates for the relative proportions of flux influence on "old" and modern arc rocks.

\begin{tabular}{lccccc}
\hline & $206 \mathrm{~Pb} /{ }^{204} \mathrm{~Pb}$ & ${ }^{207} \mathrm{~Pb} /{ }^{204} \mathrm{~Pb}$ & ${ }^{208} \mathrm{~Pb} /{ }^{204} \mathrm{P}$ & ${ }^{87} \mathrm{Sr} /{ }^{86} \mathrm{Sr}$ & ${ }^{143} \mathrm{Nd} /{ }^{144} \mathrm{Nd}$ \\
\hline Flux & 18.85 & 15.60 & 38.50 & 0.70400 & 0.51290 \\
Pacific MORB & 18.55 & 15.48 & 38.00 & 0.70255 & 0.51311 \\
Indian MORB & 18.10 & 15.45 & 37.80 & 0.70300 & 0.51305 \\
"Old" arc & 18.70 & 15.55 & 38.30 & 0.70320 & 0.51305 \\
Modern arc & 18.50 & 15.53 & 38.15 & 0.70350 & 0.51300 \\
Flux in old arc (\%) & 50 & 58 & 60 & 45 & 29 \\
Flux in new arc (\%) & 53 & 53 & 50 & 50 & 33 \\
\hline
\end{tabular}

Notes: "Old" arc represented by 'Eua, the Lau Ridge, Sites 839 and 841 , and Ata; modern arc represented by all islands from the Tofua Arc excluding Tafahi, Niuatoputapu, and Ata. The flux composition is based on measurements of rocks from Tafahi, and MORB values have been selected from the modern Lau Basin (ML), Indian Ocean, Site 836 (Indian), and Unit 7 from Site 834 (Pacific).

Clearly, the implication is that distinct differences in the isotopic composition of the Tofua Arc magmas relative to those from the older Tonga-Lau Ridge system can adequately be explained by changes in the asthenospheric mantle feeding the wedge alone, and do not require variations in either the quantity or composition of the flux from the subducting slab.

Oversby and Ewart (1972) suggested that the Pb-isotope compositions of magmas from the Tofua Arc were homogeneous, because of efficient mixing and convection resulting from rapid extension in the Lau Basin; in a sense, these authors were correct. The arc data alone, however, do not indicate a change in the asthenospheric source composition. Without the new $\mathrm{Pb}$-isotope results from the Lau Basin drill sites, no evidence exists to reveal large-scale asthenospheric replacement beneath this evolving subduction system.

\section{CONCLUSIONS}

Significant variations in the $\mathrm{Pb}$ - and $\mathrm{Sr}$-isotope compositions of samples recovered during Leg 135 provide a rare opportunity for studying the mantle dynamics beneath an evolving arc/backarc system. Although compositional variations within sites provide information on local petrogenetic processes, the wide range of values observed across the Lau Basin reveals new information regarding the evolution of the underlying mantle.

Close links between the geochemistry of magmas produced during extension and the tectonic history of the Lau Basin are clearest in the $\mathrm{Pb}$-isotope compositions. Displacement of asthenosphere similar to the source of Pacific MORB by Indian Ocean mantle has taken place as a result of slab rollback, accompanied by the southward migration of a propagating ridge tip into the extended arc crust. Magmas generated entirely within older extended arc crust in the western side of the Lau Basin owe their isotopic signatures to mixtures of Pacific mantle material and a slab-derived flux (e.g., Site 839), or to mixtures of coeval melts produced from Pacific mantle and the arc source (e.g., Site 834). Backarc magmas erupted close to the location of the propagating ridge tip, or within the crust formed by seafloor spreading, have quite different $\mathrm{Pb}$-isotope compositions, which reflect the upwelling of Indian MORB source mantle.

This process is still in operation at the Valu Fa Ridge, which is the only location along the modern spreading axes generating magmas clearly distinct from Indian MORB. Although it is true that the chemistry of magmas erupted at the Valu Fa Ridge is profoundly influenced by the adjacent active arc, we argue that the arc itself reflects the changing chemistry of the underlying mantle. Indeed, we propose that the close proximity of the southward-propagating ridge and subsequent seafloor spreading to the arc has enabled upwelling Indian Ocean asthenosphere to migrate into the sub-arc mantle. This has been further facilitated by the continuing slab rollback causing clockwise rotation of the arc.

The changing isotopic composition of arc magmatism from prebasin formation to the present-day Tofua Arc is consistent with the 
substitution of Pacific mantle wedge with a source similar to Indian Ocean asthenosphere. The implication is that isotopic variations in the arc magmatism in this region have been largely controlled by a change in the asthenospheric composition rather than in that of the downgoing slab.

\section{ACKNOWLEDGMENTS}

Our thanks to all participants on Leg 135 for their expertise, friendship, and support both during and subsequent to the cruise (and special thanks to the other igneous petrologists for being so generous with the limited supply of glass material!). We are also grateful to Mabs Johnston and Peter van Calsteren for keeping both "lab and machine" in good working order. Finally, thank you to Brian Cousens and Kathleen Johnson for their glowing reviews, and to Bill McDonough, Ted Ringwood, and Shen-su Sun for comments on a previous version of this paper. The work was supported by an NERC Special Topic grant and the dedicated efforts of Dr. Lin Kay.

\section{REFERENCES*}

Ben Othman, D., White, W.M., and Patchett, J., 1989. The geochemistry of marine sediments, island arc magma genesis and crust-mantle recycling. Earth Planet. Sci. Lett., 94:1-21.

Boespflug, X., Dosso, L., Bougault, H., and Joron, J.L., 1990. Trace element and isotopic ( $\mathrm{Sr}$ and $\mathrm{Nd}$ ) geochemistry of volcanic rocks from the Lau Basin. In von Stackelberg, U., and von Rad, U. (Eds.), Geological Evolution and Hydrothermal Activity in the Lau and North Fiji Basins, Southwest Pacific Ocean (Results of SONNE Cruise SO-35). Hannover. 503-516.

Cole, J.W., Graham, I.J., and Gibson, I.L., 1990. Magmatic evolution of Late Cenozoic volcanic rocks of the Lau Ridge, Fiji. Contrib. Mineral. Petrol., 104:540-554.

Ewart, A.W., and Hawkesworth, C.J., 1987. The Pleistocene-Recent TongaKermadec arc lavas: interpretation of new isotopic and rare earth element data in terms of a depleted mantle source model. J. Petrol., 28:495-530.

Giardini, D., and Woodhouse, J.H., 1986. Horizontal shear flow in the mantle beneath the Tonga Arc. Nature, 319:551-555.

Gill, J.B., 1976. Composition and age of Lau basin and ridge volcanic rocks: implications for evolution of an interarc basin and remnant arc. Geol. Soc. Am. Bull., 87:1384-1395.

Hawkesworth, C.J., and Ellam, R.M., 1989. Chemical fluxes and wedge replenishment rates along destructive plate margins. Geology, 17:46-49.

Hawkesworth, C.J., Gallagher, K., Hergt, J.M., and McDermott, F., 1993. Trace element fractionation processes in the generation of island arc basalts. Philos. Trans. R. Soc. London A, 342:179.

Hawkesworth, C.J., Hergt, J.M., Ellam, R.M., and McDermott, F., 1991. Element fluxes associated with subduction related magmatism. Philos. Trans. R. Soc. London A, 335:393-405.

Hawkesworth, C.J., Hergt, J.M., McDermott, F., and Ellam, R.M., 1991 Destructive margin magmatism and the contributions from the mantle wedge and subducted crust. Aust. J. Earth Sci., 38:577-594.

Hawkins, J.W., and Melchior, J.T., 1985. Petrology of Mariana Trough and Lau Basin basalts. J. Geophys. Res., 90:11431-11468.

Hynes, A., and Mott, J., 1985. On the causes of backarc spreading. Geology, $13: 387-389$
Jenner, G.A., Cawood, P.A., Rautenschlein, M., and White, W.M., 1987. Composition of back-arc basin volcanics, Valu Fa Ridge, Lau Basin: evidence for a slab-derived component in their mantle source. J. Volcanol. Geotherm. Res., 32:209-222.

Klein, E.M., Langmuir, C.H., Zindler, A., Staudigel, H., and Hamelin, B., 1988. Isotope evidence of a mantle convection boundary at the AustralianAntarctic Discordance. Nature, 333:623-629.

Loock, G., McDonough, W.F., Goldstein, S.L., and Hofmann, A.W., 1990. Isotopic compositions of volcanic glasses from the Lau Basin. Mar. Min., 9:235-245.

Mahnes, G., Minster, J.F., and Allègre, C.J., 1978. Comparative uranium-thorium-lead and rubidium-strontium study of the Saint Sverin amphoterite: consequences for early solar system chronology. Earth Planet. Sci. Lett., 39:14-24.

Mahoney, J., le Roex, A.P., Peng, Z., Fisher, R.L., and Natland, J.H., 1992. Southwestern limits of Indian ocean ridge mantle and the origin of low ${ }^{206} \mathrm{~Pb} /{ }^{204} \mathrm{~Pb}$ mid-ocean ridge basalt: isotope systematics for the central southwest Indian Ridge $\left(17^{\circ}-50^{\circ} \mathrm{E}\right)$. J. Geophys. Res., 97: 19771-19790.

McDermott, F., and Hawkesworth, C.J., 1991. Th, Pb and Sr isotope variations in young island arc volcanics and oceanic sediments. Earth Planet. Sci. Lett., 104:1-15.

Oversby, V.M., and Ewart, A., 1972. Lead isotopic compositions of TongaKermadec volcanics and their petrogenetic significance. Contrib. Mineral. Petrol., 37:181-210.

Parson, L., Hawkins, J., Allan, J., et al., 1992. Proc. ODP, Init. Repts., 135: College Station, TX (Ocean Drilling Program).

Sinton, J.M. and Detrick, R.S., 1992. Mid-ocean ridge magma chambers. J. Geophys. Res., 97:197-216.

Stern, R.J., 1982. Strontium isotopes from circum-Pacific intra-oceanic island ares and marginal basins: regional variations and implications for magmagenesis. Geol. Soc. Am. Bull., 93:477-486.

Sun, S.-S., 1980. Lead isotopic study of young volcanic rocks from mid-ocean ridges, ocean islands and island arcs. Philos. Trans. R. Soc. London A, 297:409-445.

Sun, S.-S., and McDonough, W.F., 1989. Chemical and isotopic systematics of oceanic basalts: implications for mantle composition and processes. In Saunders, A.D., and Norry, M.J. (Eds.), Magmatism in the Ocean Basins. Geol. Soc. Spec. Publ. London, 42:313-345.

Tatsumi, Y., Hamilton, D.L., and Nesbitt, R.W., 1986. Chemical characteristics of fluid phases from a subducted lithosphere and origin of arc magmas: evidence from high pressure experiments and natural rocks. J. Volcanol. Geotherm. Res., 29:293-309.

Volpe, A.M., Macdougall, J.D., and Hawkins, J.W., 1988. Lau Basin basalts (LBB): trace element and $\mathrm{Sr}-\mathrm{Nd}$ isotopic evidence for heterogeneity in back arc basin mantle. Earth Planet. Sci. Lett., 90:174-186.

Zindler, A., and Hart, S., 1986. Chemical geodynamics. Annu. Rev. Earth Planet. Sci., 14:493-571.

\footnotetext{
Abbreviations for names of organizations and publication titles in ODP reference lists follow the style given in Chemical Abstracts Service Source Index (published by American Chemical Society).
}

Date of initial receipt: 29 June 1992

Date of acceptance: 28 January 1993

Ms 135SR-142 